\title{
A phylogenetic taxonomy of the Cyrtodactylus peguensis group (Reptilia: Squamata: Gekkonidae) with descriptions of two new species from Myanmar
}

L. Lee Grismer Corresp, 1 , Perry I. Wood, Jr. ${ }^{2}$ Evan S. H. Quah ${ }^{3}$, Matthew L. Murdoch ${ }^{4}$, Marta S. Grismer ${ }^{1}$ Mark W. Herr ${ }^{2}$, Robert E. Espinoza ${ }^{5}$, Rafe M. Brown ${ }^{2}$, Aung Lin ${ }^{6}$

${ }^{1}$ Herpetology Laboratory, Department of Biology, La Sierra University, Riverside, California, United States

3 School of Biological Sciences, Universiti Sains Malaysia, Penang, Penang, Malaysia

4 Department of Biology, Villanova University, Villanova, Pennsylvania, United States

5 Department of Biology, California State University, Northridge, Northridge, California, United States

6 Department of Biology, Fauna and Flora International, Yangon, Myanmar

Corresponding Author: L. Lee Grismer

Email address: Igrismer@lasierra.edu

A phylogenetic taxonomy of species in the Cyrtodactylus peguensis group from the Ayeyarwady Basin of Myanmar is constructed based on color pattern, morphology, and molecular systematic analyses using the mitochondrial gene ND2. Newly collected samples from the type locality of $C$. peguensis and other localities indicate that this clade is endemic to central Myanmar and contains at least seven species, four of which are undescribed. Three species, including $C$. peguensis occur in the low hills of the Bago Yoma Range within the central portion of the Ayeyarwady Basin. Two of these, $C$.

myintkyawthurai sp. nov. from the northern and central Bago Yoma and C. meersi sp. nov. which is syntopic with $C$. peguensis in the southern Bago Yoma are described herein. As more lowland hilly areas bordering, and within the Ayeyarwady Basin are surveyed, more new species of this group are likely to be discovered. These discoveries continue the recent surge of descriptions of new species of Cyrtodactylus that are being discovered in Myanmar. 
1 Phylogenetic taxonomy of the Cyrtodactylus peguensis group (Reptilia: Squamata:

2 Gekkonidae) with descriptions of two new species from Myanmar

3

4 L. Lee Grismer ${ }^{1 *}$, Perry L. Wood, Jr. ${ }^{2}$, Evan S. H. Quah ${ }^{3}$, Matthew L. Murdoch ${ }^{1,4}$, Marta S.

5 Grismer ${ }^{1}$, Mark W. Herr ${ }^{2}$, Robert E. Espinoza ${ }^{5}$, Rafe M. Brown², and Aung Lin ${ }^{6}$

6

7 1Herpetology Laboratory, Department of Biology, La Sierra University, Riverside, California, 8 United States.

$9{ }^{2}$ Department of Ecology and Evolutionary Biology and Biodiversity Institute, University of

10 Kansas, Lawrence, Kansas, United States.

$11{ }^{3}$ School of Biological Sciences, Universiti Sains Malaysia, Penang, Penang, Malaysia.

$12{ }^{4}$ Department of Biology, Villanova University, Villanova, Pennsylvania, United States.

13 5epartment of Biology, California State University, Northridge, Northridge, California, United 14 States.

$15{ }^{6}$ Department of Biology, Fauna and Flora International, Yangon, Myanmar.

17 Corresponding Author:

18 Grismer, L. Lee

19 lgrismer@lasierra.edu

\section{ABSTRACT}

22 A phylogenetic taxonomy of species in the Cyrtodactylus peguensis group from the Ayeyarwady

23 Basin of Myanmar is constructed based on color pattern, morphology, and molecular systematic 24 analyses using the mitochondrial gene ND2. Newly collected samples from the type locality of 25 C. peguensis and other localities indicate that this clade is endemic to central Myanmar and 26 contains at least seven species, four of which are undescribed. Three species, including $C$.

27 peguensis occur in the low hills of the Bago Yoma mountain range within the central portion of 
28 the Ayeyarwady Basin. Two of these, C. myintkyawthurai sp. nov. from the northern and central

29 Bago Yoma and C. meersi sp. nov. which is syntopic with C. peguensis in the southern Bago

30 Yoma are described herein. As more lowland hilly areas bordering, and within the Ayeyarwady

31 Basin are surveyed, more new species of this group are likely to be discovered. These

32 discoveries continue the recent surge of descriptions of new species of Cyrtodactylus that are

33 being discovered in Myanmar.

\section{INTRODUCTION}

36 The Gekkota (geckos and pygopods) comprises one of the most diverse lizard lineages in the world, containing approximately 1777 species to date (Uetz et al. 2018). Within the Gekkota, Bent-toed Geckos (Cyrtodactylus Gray) are not only the most speciose genus, but the most rapidly growing in terms of the annual rate of newly described species (Uetz et al. 2018). This is especially true throughout Indochina and Sundaland with the Southeast Asian nation of Myanmar being no exception. In fact, the number of new species of Cyrtodactylus discovered in Myanmar has increased from 19 to 34 (79\%) in just the last year alone (see Grismer et al. 2017a, 2018). Notably, this increase in diversity is not due to molecular analyses partitioning out species groups and adjusting the taxonomy accordingly but rather it is the result of discoveries made during recent expeditions into some of the more remote regions of the country.

One of the more enigmatic species in Myanmar, Cyrtodactylus peguensis (Boulenger, 1893), was described from two specimens (syntypes) collected by Signor L. Fea in 1887 from Palon [Hpa Lon], Bago Division in southern Myanmar. Unfortunately, one of the syntypes has been lost and apparently was never accessioned into the British Museum of Natural History

50 (Patrick Campbell in litt. 2018). It is clear, however, that the specimen did exist and was available to Smith (1921) based on his statement that the syntypes have "two series of (6-8) large round spots on the back [referring to BMNH 1946.8.23] or [our italics] with the spots confluent transversely [referring to the specimen illustrated in Boulenger (1893)]". Following its 
55 to accumulate populations from throughout Indochina ranging from Vietnam to Thailand

56 (Laidlaw, 1901; Boulenger, 1912; Annandale, 1913; Smith, 1916, 1921, 1930, 1935).

57 Cyrtodactylus peguensis is still reported to occur in western and southern Thailand (i.e., Taylor,

58 1962, 1963; Manthey \& Grossman, 1997; Chan-ard, et al., 2015) and some (with no voucher)

59 have even reported it from northern Peninsular Malaysia (Ulber \& Schäfer, 1989; Denzer \&

60 Manthey, 1991). Taylor (1962) recognized one of the southern Thai populations from Nakhon Si

61 Thammarat Province as C. p. zebriacus and another from Trang Province, $70 \mathrm{~km}$ to the south in

62 the same mountain range as C. p. peguensis. Subsequent authors (e.g., Manthey \& Grossmann,

63 1997; Chan-ard, et al., 1999; Das, 2010), however, implicitly considered both populations as C.

64 p. zebriacus but did so without comment. In a recent phylogeny, Grismer et al. (2017a) noted

65 that C. p. zebriacus is a member of a lineage they designated as the Indochinese clade and that it

66 is only distantly related to species of the Indo-Burmese clade that contains true C. peguensis

67 group species (i.e., C. pyinyaungensis, see discussion in Grismer et al., [2017]), thus bringing

68 into question the species identity of the Thai populations.

69 In order to construct a taxonomy of this group that is consistent with its evolutionary

70 history, an understanding of the phylogenetic relationships of true Cyrtodactylus peguensis from

71 the type locality to the other populations in Myanmar and to C. p. zebriacus is paramount.

72 Therefore, we collected two specimens from the Myin Mo Shwe Taung Pagoda, $9.5 \mathrm{~km}$ east of

73 Hpa Lon village (the type locality) in the western foothills of the southern portion of the Bago

74 Yoma mountain range as this locality constitutes the closest, most suitable, habitat for $C$.

75 peguensis (Fig. 1). To this we added eight samples from Mt. Popa from the northernmost section

76 of the Bago Yoma Range (Mandalay Division). This population resembles C. peguensis in color

77 pattern but has been referred to as C. fea (Wood et al., 2012; Agarwal et al., 2014; Brennan et al.

78 2017) but later informally re-identified as C. peguensis (see discussion in Grismer et al.,

79 2017:3). We also included seven samples that were accessioned into the California Academy of

80 Sciences (CAS) as C. peguensis: three from the central portion of the Bago Yoma Range (Bago

81 Division), two from the Panlaung-Pyadalin Cave Wildlife Sanctuary (Shan State), one from 
82 Aung Ya Village (Rakhine State), and one from the Shwe Settaw Wildlife Sanctuary (Magway

83 Division). Last, we included a sample of C. p. zebriacus from Nahkon Si Thammarat Province,

84 Thailand and three samples of C. pyinyaungensis from Pyinyaung Village, Shan State — a species

85 that has been hypothesized to be closely related to C. peguensis (Grismer et al., 2017a). Tissues

86 from these samples were used to construct a molecular phylogeny based on 1467 base pairs of

87 the mitochondrial gene NADH dehydrogenase subunit 2 (ND2) and its flanking tRNA regions.

88 Morphological and color pattern data taken from specimens from the type locality (including the

89 remaining syntype), Mt. Popa, the central Bago Yoma, and C. pyinyaungensis were analyzed and

90 the results compared to the molecular phylogeny. We also examined 16 specimens of $C$. $p$.

91 zebriacus from three localities in southern Thailand and compared them to species of the

92 peguensis group. The results of these analyses corroborate one another and indicate that in order

93 to bring the taxonomy of the peguensis group in line with its evolutionary history (i.e.,

94 phylogeny), at least four new species must be described and that C. p. zebriacus should be

95 elevated to species status being that it is not closely related to or morphologically similar to any

96 species in the peguensis group.

\section{MATERIALS AND METHODS}

99

\section{Species delimitation}

101 The general lineage concept (GLC: de Queiroz 2007) used herein proposes that a species constitutes a population of organisms independently evolving from other such populations owing to a lack of gene flow. By "independently," it is meant that new mutations arising in one species cannot spread readily into another species (Barraclough et al., 2003 and de Queiroz 2007). Increasingly, integrative studies on the nature and origins of species are using a wider range of empirical data to delimit species boundaries (Coyne \& Orr 1998; Knowles \& Carstens 2007, Fontaneto et al., 2007; Feulner et al., 2007; Leaché et al., 2009), rather than relying solely on traditional taxonomic methods. Under the GLC herein, molecular phylogenies were used to infer 
109 species boundaries and univariate analysis of variance (ANOVA) and multivariate principal

110 component analysis (PCA) and discriminate analysis of principal components (DAPC) of

111 morphological data were used to describe those boundaries. These boundaries were cross-

112 checked using a Generalized Mixed Yule Coalescent (GMYC) approach (Pons et al., 2006), thus

113 providing an independent framework to complement the empirically based thresholds of the

114 morphological and molecular analyses. The GMYC approach is a method for delimiting species

115 from single-locus gene trees by detecting genetic clustering beyond the expected levels of a null

116 hypothesis which infers that all individuals of a population form a genetically, interacting nexus.

117 In clades where effective population sizes are relatively low and divergence times among the

118 populations are relatively high, the single-threshold version of the model (such as that used

119 herein) outperforms the multi-threshold version (Fujisawa \& Barrenclough 2013). The GMYC

120 relies on the prediction that independent evolution leads to the appearance of distinct genetic

121 clusters, separated by relatively longer internal branches (Barraclough et al., 2003; Acinas et al.,

122 2004). Such groups therefore, diverge into discrete units of morphological and genetic variation

123 that are recovered with surveys of higher clades. The analysis was run on the web server at

124 http://species.h-its.org/gmyc/.

125

126 Molecular data and analyses

127 The data set of Grismer et al. (2017a), which included exemplars of all the major Cyrtodactylus

128 clades in Agarwal et al. (2014), was augmented with 17 samples purported to be C. peguensis,

129 totaling 222 ingroup samples. Hemidactylus angulatus Hallowell, H. frenatus Duméril \& Bibron,

130 H. garnotii Duméril \& Bibron, H. mabouia (Moreau de Jonnès), and H. turcicus (Linnaeus)

131 served as outgroups following Grismer et al. (2017a). All new sequences were deposited in

132 GenBank (Table 1). Genomic DNA was isolated from liver or skeletal muscle tissue stored in

$13395 \%$ ethanol using a Maxwell ${ }^{\circledR}$ RSC Tissue DNA kit on the Promega Maxwell ${ }^{2}$ RSC extraction

134 robot. ND2 was amplified using a double-stranded Polymerase Chain Reaction (PCR) under the

135 following conditions: $1.0 \mu 1$ genomic DNA (10-30 $\mu \mathrm{g}), 1.0 \mu 1$ light strand primer (concentration 
$13610 \mu \mathrm{M}), 1.0 \mu \mathrm{l}$ heavy strand primer (concentration $10 \mu \mathrm{M}), 1.0 \mu$ l dinucleotide pairs $(1.5 \mu \mathrm{M})$, $1372.0 \mu \mathrm{l} 5 \mathrm{x}$ buffer $(1.5 \mu \mathrm{M}), \mathrm{MgCl} 10 \mathrm{x}$ buffer $(1.5 \mu \mathrm{M}), 0.1 \mu \mathrm{l}$ Taq polymerase $(5 \mathrm{u} / \mu \mathrm{l})$, and $6.4 \mu \mathrm{l}$

138 ultra-pure $\mathrm{H}_{2} \mathrm{O}$. PCR reactions were executed on Bio-Rad gradient thermocycler under the

139 following conditions: initial denaturation at $95^{\circ} \mathrm{C}$ for $2 \mathrm{~min}$, followed by a second denaturation at $14095^{\circ} \mathrm{C}$ for $35 \mathrm{~s}$, annealing at $48-52^{\circ} \mathrm{C}$ for $35 \mathrm{~s}$, followed by a cycle extension at $72^{\circ} \mathrm{C}$ for $35 \mathrm{~s}$, for

14131 cycles. All PCR products were visualized using electrophoresis on a $1.0 \%$ agarose gel.

142 Successful PCR products were sent to GENEWIZ® for PCR purification, cycle sequencing, 143 sequencing purification, and sequencing using the same primers as in the amplification step 144 (Table 2). Sequences were analyzed from both the 3' and the 5' ends separately to confirm 145 congruence between the reads. Forward and reverse sequences were uploaded and edited in

146 Geneious $^{\mathrm{TM}}$ version v6.1.8. Following sequence editing we aligned the protein-coding region and 147 the flanking tRNAs using the MAFTT v7.017 (Katoh \& Kuma, 2002) plugin under the default 148 settings in Geneious ${ }^{\mathrm{TM}}$ (Kearse et al., 2012). Mesquite v3.04 (Maddison \& Maddison, 2015) was 149 used to calculate the correct amino acid reading frame and to confirm the lack of premature stop 150 codons in the ND2 portion of the DNA fragment.

151 Two model-based phylogenetic analyses, maximum likelihood (ML) and Bayesian

152 Inference (BI) were employed. The ML analysis was implemented in IQ-TREE (Nguyen et al., 153 2015) which employs a Bayesian Information Criterion (BIC) algorithm to calculate that $154 \mathrm{~K} 3 \mathrm{P}+\mathrm{I}+\mathrm{G} 4$ was the best-fit model of evolution for the tRNA, TVM+F+I+G4 the best-fit model 155 for the first codon position, $\mathrm{TIM} 3 \mathrm{~F}+\mathrm{I}+\mathrm{G} 4$ for the second codon position, and $\mathrm{GTR}+\mathrm{F}+\mathrm{ASC}+\mathrm{G} 4$ 156 for the third codon position. Shimodaira-Hasegawa-like approximate likelihood ratio test (LRT; 157 Guindon et al., 2010) and Ultrafast Bootstrap Approximation (UFB; Hoang et al., 2017) using

1581000 bootstrap replicates were used to construct a final consensus tree. Nodes with UFB values 159 of 95 and above and LRT values of 0.80 and above were considered significantly supported. A 160 BI analysis was implemented in MrBayes 3.2.3. on XSEDE (Ronquist et al., 2012) using 161 CIPRES (Cyberinfrastructure for Phylogenetic Research; Miller et al., 2010). An approximation 162 of the same models of evolution generated in IQ-TREE for the ML analysis were employed in 
163 the BI analysis where GTR $+\mathrm{I}+\mathrm{G}$ was estimated to be the best-fit model of evolution for all codon

164 positions and $\mathrm{HKY}+\mathrm{G}$ was the model of evolution for the tRNA. Two simultaneous runs were

165 performed with four chains, three hot and one cold. The simulation ran for 10,000,000

166 generations, was sampled every 1000 generations using the Markov Chain Monte Carlo

167 (MCMC), and the first 25\% of each run were discarded as burn-in. Stationarity and .p files from

168 each run were checked in Tracer v1.6 (Rambaut et al., 2014) to ensure effective sample sizes

169 (ESS) were above 200 for all parameters. Nodes with Bayesian posterior probabilities (BPP) of

1700.95 and above were considered well-supported (Hulsenbeck et al., 2001; Wilcox et al., 2002).

171 After removing outgroup taxa, MEGA7 (Kumar et al., 2016) was used to calculate uncorrected

172 pairwise sequence divergence of the 21 ingroup samples.

173

174 Morphological data and analyses

175 Color pattern notes were taken from living and preserved specimens and digital images of living

176 specimens of all possible age classes prior to preservation. Measurements were taken on the right

177 side of the body when possible to the nearest $0.1 \mathrm{~mm}$ by MSG using dial calipers under a Leica

178 Wild M 10 stereo dissecting microscope following Grismer et al., (2017a). Measurements taken

179 were: snout-vent length (SVL), taken from the tip of snout to the vent; tail length (TL), taken

180 from the vent to the tip of the tail, original or regenerated; tail width (TW), taken at the base of

181 the tail immediately posterior to the postcloacal swelling; forearm length (FL), taken on the

182 dorsal surface from the posterior margin of the elbow while flexed $90^{\circ}$ to the inflection of the

183 flexed wrist; tibia length (TBL), taken on the ventral surface from the posterior surface of the

184 knee while flexed $90^{\circ}$ to the base of the heel; axilla to groin length (AG), taken from the

185 posterior margin of the forelimb at its insertion point on the body to the anterior margin of the

186 hind limb at its insertion point on the body; head length (HL), the distance from the posterior

187 margin of the retroarticular process of the lower jaw to the tip of the snout; head width (HW),

188 measured at the angle of the jaws; head depth (HD), the maximum height of head measured from

189 the occiput to the throat; eye diameter (ED), the greatest horizontal diameter of the eye-ball; eye 
190 to ear distance (EE), measured from the anterior edge of the ear opening to the posterior edge of

191 the eye-ball; eye to snout distance (ES), measured from anteriormost margin of the eye-ball to

192 the tip of snout; eye to nostril distance (EN), measured from the anterior margin of the eye ball to

193 the posterior margin of the external nares; inter orbital distance (IO), measured between the

194 anterior edges of the orbit; ear diameter (EL), the greatest vertical distance of the ear opening;

195 and internarial distance (IN), measured between the nares across the rostrum.

196 Meristic characters taken were the numbers of supralabial (SL) and infralabial (IL) scales

197 counted from the largest scale immediately below the middle of the eyeball to the rostral and

198 mental scales, respectively; the number of paravertebral tubercles (PVT) between limb insertions

199 counted in a straight line immediately left of the vertebral column; the number of longitudinal

200 rows of body tubercles (LRT) counted transversely across the center of the dorsum from one

201 ventrolateral fold to the other; the number of longitudinal rows of ventral scales (VS) counted

202 transversely across the center of the abdomen from one ventrolateral fold to the other; and the

203 total number of subdigital lamellae (4TL) beneath the fourth toe. The total number of femoral

204 pores (FP) in males (i.e., the sum of the number of enlarged pore-bearing femoral scales from

205 each leg combined as a single metric; the number of precloacal pores in (PP) in males; the

206 number of rows of post-precloacal scales (PPS) on the midline between the enlarged precloacal

207 scales and the vent (see Grismer et al., 2017a:Fig. 4); number of body bands (BB) or large,

208 transversely oriented, dark paravertebral spots between the nuchal loop (dark band running from

209 eye to eye) and the hind limb insertions not including the nape or postsacral bands; the number

210 of light caudal bands (LCB) on an original tail; and the number of dark caudal bands (DCB) on

211 an original tail. Non-meristic morphological characters evaluated were the degree of body

212 tuberculation - weak tuberculation referring to dorsal body tubercles that are relatively low,

213 small, less densely packed, and weakly keeled whereas prominent tuberculation refers to

214 tubercles that are larger, higher (raised), and prominently keeled (see Grismer et al., 2017a:Fig.

215 6); and the relative length to width ratio of the transversely expanded, median subcaudal scales.

216 Color pattern characters (see Grismer et al., 2017a:Fig. 5) evaluated were the dorsal body bands 
217 bearing paired, paravertebral elements or fused medially; top of head bearing combinations of

218 dark diffuse mottling or dark, distinct blotches overlain with a light-colored reticulating network

219 or not; and light caudal bands encircling tail or not.

$220 \quad$ All statistical analyses were performed using the platform R v 3.2.1 (R Core Team 2015).

221 Given that sample sizes from the five populations tested (see below) were unequal, a Levene's

222 test was conducted to test for homogeneity of variances among each meristic character prior to

223 an analysis of variance (ANOVA). A Welsh's ANOVA was conducted on characters with

224 unequal variances (i.e., $p$ values $\geq 0.05$ in the Levene's test) to test for the presence of

225 statistically significant mean differences $(p \leq 0.05)$ in the data set. Characters containing

226 statistical differences were subjected to a Tukey HSD test to ascertain which population pairs

227 differed significantly from each other for those characters.

228 Principal component analysis (PCA) and discriminant analysis of principal components

229 (DAPC) using the ADEGENET package in R (Jombart et al., 2010) were used to determine if

230 the populations sampled occupied unique positions in morphospace and the degree to which their

231 variation in morphospace coincided with the putative species boundaries delimited by the

232 molecular phylogenetic, univariate, and GMYC analyses. PCA, implemented by the prcomp

233 command in $\mathrm{R}$, is an indiscriminate analysis plotting the overall variation among individuals (i.e.

234 data points) while treating each independently (i.e. not coercing them into pre-defined groups).

235 Femoral and precloacal pore counts were excluded from the PCA due to their presence in only

236 males. For all other characters, both sexes and all size classes were used. All data used in the

237 PCA were log-transformed and scaled to their standard deviation prior to analysis in order to

238 normalize their distribution so as to ensure characters with very large and very low values did not

239 over-leverage the results owing to intervariable nonlinearity and to insure the data were analyzed

240 on the basis of correlation not covariance. A vectorial representation of the multivariate data by

241 use of a biplot analysis was implemented using the ggbiplot command in R. Here, the

242 information for both the populations/species and the characters are overlain on the PCA plot.

243 Groups of vectors pointing in the same direction are indicative of characters that vary in the same 
244 manner across multivariate space and the vector angles (based on either the $x$ or $y$ axis) are 245 proportional to their degree of covariation. In order to determine which centroids (i.e., means) of 246 the PCA plots differed significantly from one another, a modified version of the broken stick 247 model (Cangelosi \& Goriely 2007) from the VEGAN package in R was implemented using the 248 bs command. This statistical model implements a stopping rule (Jackson 1993) in order to 249 determine the number of interpretable PCs (i.e., those that capture the most amount of variation 250 in the data set with the least amount of noise) to retain for interpretation prior to PC degeneration 251 (subsequent PCs represent negligible structure in the data and amount mostly to noise). The 252 analysis using this model produces overlapping curves of eigenvalues and broken stick values and proposes that the number of retained PCs should have eigenvalues higher than their corresponding random broken stick components. For this analysis, PC1 which accounts for 44\% of the total variation in the data set, was the only PC retained. The data points from PC1 were subjected to a Welsh's ANOVA and a Tukey HSD test to ascertain which pairs of species centroids differed significantly from one another.

The DAPC places the individuals of each pre-defined population into separate clusters

259 (i.e., plots of points) bearing the smallest within-group variance that produce linear combinations 260 of centriods having the greatest between-group variance (linear distance; Jombart et al., 2010).

261 DAPC relies on log transformed and scaled data from the PCA as a prior step to ensure that the 262 variables analyzed are not correlated and number fewer than the sample size. Selecting the 263 principal components generated by the DAPC that collectively account for at least $90 \%$ of the 264 variation in the data set are retained for the analysis (Jombart et al., 2010) and a dimension 265 reduction mechanism to remove noise in the data set. Retaining too many variables, forces false 266 structure to appear in the data. Retaining too few, runs the risk of missing true structure in the 267 data set (Cangelosi \& Goriely 2007).

268 Museum abbreviations follow Sabaj (2016) except for LSUHC referring to the La Sierra 269 University Herpetological Collection, La Sierra University, Riverside, California, 92505, USA; 270 and MS referring to Montri Sumontha, Ranong Marine Fisheries Station, Ranong 85000, 
271 Thailand. Ministry of Natural Resources and Environmental Conservation Forest Department of

272 Myanmar provided collecting and export permits. The electronic version of this article in

273 Portable Document Format (PDF) will represent a published work according to the International

274 Commission on Zoological Nomenclature (ICZN), and hence the new names contained in the

275 electronic version are effectively published under that Code from the electronic edition alone.

276 This published work and the nomenclatural acts it contains have been registered in ZooBank, the

277 online registration system for the ICZN. The ZooBank LSIDs (Life Science Identifiers) can be

278 resolved and the associated information viewed through any standard web browser by appending

279 the LSID to the prefix http://zoobank.org/. The LSID for this publication is:

280 urn:lsid:zoobank.org:act: 9645421A-0997-487C-B26B-2030FC42D264

281 . The online version of this work is archived and available from the following digital

282 repositories: PeerJ, PubMed Central and CLOCKSS.

283 Brigham Young University's Institutional Animal Care and Use Committee (IACUC) has

284 approved the animal use protocol for this study (protocol \# 160401). Collecting permits were

285 granted to Fauna \& Flora International (FFI) by Mr. Win Naing Thaw of the Ministry of natural

286 Resources and Environmental Conservation Forest Department. The authors worked under the

287 umbrella of FFI.

288

289 RESULTS

290 The ML and BI analyses produced trees with identical topologies and strong nodal support at

291 nearly every node (Fig. 2). All but one of the Burmese populations included in the analyses that

292 have been formally or informally considered conspecific with or allied to Cyrtodactylus

293 peguensis are recovered as a monophyletic group. Cyrtodactylus annandalei Bauer was

294 recovered as a closely related sister species to this monophyletic group and distantly related to all

295 other species of the Indo-Burma clade (Fig. 2). As such, it and the other populations are referred

296 to here as the peguensis group. The specimen (CAS 22143) not included in the peguensis group

297 from Aung Ya Village, Rakhine State was recovered as an undescribed sister species to $C$. 
298 ayeyarwadyensis Bauer. Surprisingly, the two samples from the Myin Mo Shwe Taung Pagoda

299 from $9.5 \mathrm{~km}$ east of the type locality of C. peguensis were not each other's closest relatives and

300 share an 10.3\% uncorrected pairwise sequence divergence between them despite being collected

301 within $200 \mathrm{~m}$ of one another (Table 3).

302 In comparing each specimen from the Myin Mo Shwe Taung Pagoda to the syntype of

303 Cyrtodactylus peguensis (BMNH 1946.8.23.10), it is clear that LSUHC 13454 is much closer

304 morphologically to the type than is LSUHC 13455 (Table 4). The syntype and LSUHC 13454

305 have 17-19 longitudinal rows of dorsal tubercles (LRT) vs. 13 in LSUHC 13455, 36 or 37

306 ventral scales (VS) vs. 32, 19 subdigital lamellae on the fourth toe (4TL) vs. 17, and three vs.

307 two post-precloacal scale rows. Furthermore, the syntype and LSUHC 13454 group closely

308 together in the PCA where $44 \%$ of the variation in the data set occurs along the first principal

309 component (PC1) and loads most heavily for fourth toe lamellae and infralabial scales and $16 \%$

310 of the variation occurs along PC2 and loads most heavily for body bands (Table 5, Fig. 3).

311 Additionally, the syntype and LSUHC 13454 are well-separated from LSUHC 13455 in both the

312 PCA and DAPC analyses (Fig. 3). Therefore, we consider LSUHC 13454 to be C. peguensis and

313 LSUHC 13455 to be a new species (described below). The analyses also recovered the Shan

314 State specimens (CAS 226142-43) from the Pyadalin Cave region and CAS 226139 from the

315 Shwe Settaw Wildlife Sanctuary, Magway Division to be distinct from one another and from all

316 other peguensis group lineages and will be described elsewhere when specimens become

317 available. The PCA and DAPC analyses recovered C. pyinyaungensis and C. peguensis as the

318 most morphospatially distinct species in the peguensis group (Fig. 3) and the biplot analysis

319 shows a distinct dichotomy along PC1 in character variation between the number body bands

320 which do not covary with any of the remaining covarying characters. All species are widely

321 separated in the DAPC analysis.

322 As predicted based on morphology and color pattern (Grismer et al. 2017a),

323 Cyrtodactylus pyinyaungensis is the sister species of C. peguensis. Together, these sister species

324 are most closely related to sister populations from the central Bago Yoma, Bago Division and 
325 Mt. Popa from the northern Bago Yoma, Mandalay Division. These reciprocally monophyletic 326 sister populations overlap in morphospace (Fig. 3) and are not morphologically distinguishable

327 from one another (Table 6) nor do the centroids of their plots differ significantly $(p=0.60)$. They

328 share an uncorrected pairwise sequence divergence of 3.0-4.0\% despite the samples being 329 separated by approximately $230 \mathrm{~km}$ (Table 3). This is in stark contrast to C. peguensis (LSUHC

330 13454) and LSUHC 13455 from the Myin Mo Shwe Taung Pagoda which share an 10.3\%

331 sequence divergence yet were found only $200 \mathrm{~m}$ apart. The central Bago Yoma and Mt. Popa 332 populations are morphologically distinct from all other species in the peguensis group (Tables 7,

333 8) and differ from them by an uncorrected pairwise sequence divergence of $4.0-16.0 \%$ (Table 3 ).

334 Despite the fact that Mt. Popa is an isolated volcano delimiting the disjunct northern limit of the

335 Bago Yoma, the intervening lowlands contain scattered, low-lying hills and suitable habitat

336 likely provide opportunities for gene flow or at least very recent gene flow. As such, we consider

337 these populations conspecific and are described below as a new species.

338 The GMYC species delimitation independently recovered the same species inferred from

339 the above analyses. Sukumaran \& Knowles (2017) demonstrated that species delimitation

340 methods generally overestimate species diversity by recovering clades not species and that

341 additional criteria such as morphology should be used in conjunction with these analyses.

342 Fujisawa \& Barraclough (2013) also note that the GMYC approach should be used in

343 conjunction with additional independent data. We agree with these recommendations and believe

344 the GMYC recovered noteworthy interpopulational genetic structure among individuals collected

345 just meters apart that corroborates species boundaries characterized by the morphological data.

346 Therefore, we base our species delimitations on a more integrative approach.

As previously hypothesized on the basis of molecular evidence (Grismer et al. 2017a,

$3482018 a, b)$, the phylogenetic analyses indicate that Cyrtodctylus peguensis zebraicus of southern

349 Thailand is not closely related to C. peguensis but nested within the oldhami group (sensu

350 Connette et al. 2017) of the Indochinese clade and not with species of the peguensis group of the 351 Indo-Burmese clade (Fig. 2). It is shares a sequence divergence of $28.0-31.3 \%$ amonng species 
352 of the peguensis group (Table 3). Therefore, we remove C. p. zebriacus from the synonymy of $C$. 353 peguensis and elevate it to the full species, C. zebriacus Taylor, 1962. Based on the examination

354 of eight specimens of C. zebriacus from Ko Samui Island, Surat Thani Province (CAS 23568-

355 75), six specimens from Trang Province (FMNH 176851-54, 176857, 177328), and two

356 specimens from Nakhon Si Thammarat, Province (FMNH 178286 and 215984), C. zebriacus

357 differs from all members of the peguensis group by having larger and more strongly keeled body

358 tubercles; no femoral pores; a dorsal pattern that is generally banded or has a more reticulated 359 pattern as opposed to being composed of large, dark, paravertebral spots or hour glass-shaped

360 bands; the top of the head bears a diffuse, reticulated pattern as opposed to having large, dark,

361 well-defined spots; having black and white caudal bands of nearly equal width as opposed to

362 having dark-brown and yellow caudal bands of unequal width; and the light-colored (i.e. white)

363 caudal bands encircle the tail as opposed to being incomplete in the subcaudal region (Fig 4).

364

365

SYSTEMATICS AND TAXONOMY

Below we define and diagnose the Cyrtodactylus peguensis group and describe two of the new species recovered in the phylogenetic and morphological analyses. We also re-describe Cyrtodactylus peguensis based on one of the syntypes (BM 1946.8.23.10) and the newly collected specimen (LSUHC 13454) from $9.5 \mathrm{~km}$ east of the type locality. We do this in order to correct errors and omissions in the original description (Boulenger, 1893) and subsequent descriptions of the syntypes (Smith, 1921) as well as to present new characters used herein to diagnose different species in the peguensis group.

373

Cyrtodactylus peguensis group

Definition and diagnosis. The Cyrtodactylus peguensis group ranges throughout the low hills of the Ayeyarwady Basin and its low hilly margins from the Alaungdaw Kathapa National Park, Magwe Division in the northeastern foothills of the Chin Hills, eastward to the Panlaung and 
379

380

381

382

383

384

385

386

387

388

389

390

391

392

393

394

395

396

397

398

399

400

401

402

403

404

405

Pydalain Cave Wildlife Sanctuary, Shan State in the northwestern foothills of the Shan Hills, and southward through the Bago Yoma Range to the Myin Mo Shwe Taung Pagoda, Bago Division in the southern Bago Yoma Range (Fig. 1). This clade is composed of four nominal species $C$. peguensis (Boulenger), C. annandalei Bauer, two new species from the Bago Yoma range (see below), C. pyinyaungensis Grismer et al., two undescribed species Cyrtodactylus sp. 1 and Cyrtodactylus sp. 2 and is defined by the following range of characters: seven or eight supralabials, 28-33 paravertebral scales, 13-23 longitudinal rows of dorsal tubercles, 32-43 ventral scales, 10-19 fourth toe lamellae, 12-22 femoral pores in males, 7-12 precloacal pores in males, two or three post-precloacal scales, 4-6 dark transverse body bands between limb insertions usually bearing paravertebral elements, 9-13 light and dark caudal bands, dorsal body tubercles domed and weakly keeled and conical to raised and moderately to strongly keeled, top of the head blotched or patternless never bearing a reticulated pattern, and a maximum SVL of at least 55-75.1 mm (Table 7).

\section{Cyrtodactylus peguensis (Boulenger, 1893)}

\section{Pegu Bent-toed Gecko}

\section{(Fig. 5)}

Gymnodactylus peguensis Smith 1921:29; 1935:52 in part. Wermuth 1965:63 in part. Cyrtodactyuls peguensis Taylor 1963:728 in part; Denzer \& Manthey 1991:314 in part; Cox et al. 1998:87 in part; Pianka \& Vitt 2003:175 in part; Manthey \& Grossmann 1997:225 in part; Das 2010:213 in part; Grismer et al. 2017a:91 in part; Brennan et al. 2017:3, in part. Cyrtodactylus (Cyrtodactylys) peguensis Rösler 2000:66 in part.

Other synonymies exist in several popular herpetoculrural outlets but are not listed here. Syntype. Adult male BM 1946.8.23.10 collected in 1887 by Signor L. Fea from "Palon" [Hpa Lon], "Pegu” [Bago Region], Taikkyi Township, Yangon (north) District, Myanmar. Hpa-Lon is a small village in the Ayeyarwady Basin $9.5 \mathrm{~km}$ west of the western foothills of the southern 
406 portion of the Bago Yoma Range where Fea reported making zoological collections (Fea, 1897).

407 Being that foothills are the closest suitable habitat for Cyrtodactylus peguensis east of Pa-Lon,

408 we restrict the type locality to the Myin Mo Swhe Taung Pagoda, Bago Division, Taikkyi

409 Township, Yangon (north) District, Myanmar $\left(17.46272^{\circ} \mathrm{N}, 96.01624^{\circ} \mathrm{E}\right.$, elevation $\left.162 \mathrm{~m}\right)$

410 situated within these foothills where we collected an additional specimen (LSUHC 13455). The

411 other syntype could not be located.

412 Additional specimen. Subadult male (LSUHC 13454) collected by Myint Kwaw Thura on 18

413 May 2017 along a dirt road just below the Myin Mo Swhe Taung Pagoda.

414 Diagnosis. Cyrtodactylus peguensis differs from other species of the peguensis group by having

415 the unique combination of seven supralabial and infralabial scales; 31 or 32 paravertebral

416 tubercles; 17-19 longitudinal rows of body tubercles; 36 or 37 ventral scales; 19 subdigital

417 lamellae on the fourth toe; 17-19 femoral pores in males; eight precloacal pores in males; three

418 rows of post-precloacal scales; and domed to weakly conical and weakly keeled body tubercles;

419 and a maximum SVL of $70 \mathrm{~mm}$ (Table 7).

420 Description based on BM 1946.8.23.10 and LSUHC 13454. Maximum SVL 70.0 mm; head

421 moderate in length (HL/SVL 0.28-0.29), wide (HW/HL 0.57-0.65), somewhat flattened (HD/HL

422 0.44), distinct from neck, triangular in dorsal profile; lores inflated, prefrontal region concave,

423 canthus rostralis rounded; snout elongate (ES/HL 0.38-0.42), rounded in dorsal profile; eye large

424 (ED/HL 0.21-0.24); ear opening triangular, moderate in size (EL/HL 0.12); eye to ear distance

425 greater than diameter of eye; rostral rectangular, partially divided dorsally, bordered posteriorly

426 by large left and right supranasals contacting on midline or separated by small internasal,

427 laterally by first supralabials; external nares bordered anteriorly by rostral, dorsally by large

428 supranasal, posteriorly by two small postnasals, ventrally by first supralabial; seven (R,L)

429 rectangular supralabials extending to below midpoint of eye; seven $(\mathrm{R}, \mathrm{L})$ infralabials tapering

430 smoothly to below posterior margin of orbit; scales of rostrum and lores flat, larger than granular

431 scales on top of head and occiput; scales on top of head and occiput intermixed with slightly

432 enlarged tubercles; dorsal supraciliaries not elongate or keeled; mental triangular, bordered 
433 laterally by first infralabials and posteriorly by large, left and right trapezoidal postmentals that 434 contact medially for $40-60 \%$ of their length posterior to mental; one row of slightly enlarged 435 chinshields extending posteriorly to fourth infralabial; and gular and throat scales small, 436 granular, grading posteriorly into larger, flatter, smooth, subimbricate to imbricate, pectoral and 437 ventral scales.

438 Body relatively short (AG/SVL 0.42-0.43) with weak ventrolateral folds; dorsal scales small, interspersed with small, domed to weakly conical, semi-regularly arranged weakly keeled tubercles; tubercles extend from occiput onto base of tail but no farther; tubercles on occiput and nape small, those on posterior portion of body larger and keeled; approximately 17-19

442 longitudinal rows of dorsal tubercles; 31 or 32 paravertebral tubercles; approximately 36 or 37

443 flat, imbricate, ventral scales larger than dorsal scales composing 36 or 37 rows; eight pore444 bearing precloacal scales; three rows of large post-precloacal scales; and no deep precloacal 445 groove or depression.

Forelimbs moderate in stature, relatively short (FL/SVL 0.14-0.16); flat scales of forearm larger than those on body, not interspersed with tubercles; palmar scales flat to rounded and slightly raised; digits well-developed, relatively short, inflected at basal, interphalangeal joints; digits slightly narrower distal to inflections; claws well-developed, sheathed by a dorsal and ventral scale; hind limbs more robust than forelimbs, moderate in length (TBL/SVL 0.17-0.18), covered dorsally by granular scales interspersed with slightly larger, weakly keeled tubercles and anteriorly by large, flat, imbricate scales; ventral scales of femora flat, imbricate, larger than dorsals, lacking a row of enlarged femoral scales; 8 or $9(\mathrm{R})$ and 9 or 10 (L) pore-bearing

454 femoral scales; small postfemoral scales form an abrupt union with large, flat ventral scales of 455 posteroventral margin of thigh; subtibial scales flat, imbricate; plantar scales granular, slightly 456 raised; digits relatively short, well-developed, inflected at basal, interphalangeal joints; 19 457 subdigital lamellae on fourth toe; and claws well-developed, base of claw sheathed by a dorsal 458 and ventral scale; two or three enlarged postcloacal tubercles at base of tail; and postcloacal 459 scales flat. 
461 at base, tapering to a point; dorsal scales flat, imbricate, becoming larger posteriorly; subcaudal

462 scales slightly larger than dorsal scales; two enlarged postcloacal tubercles at base of tail; and

463 postcloacal scales flat. Original tail (LSUHC 13454) moderate in proportions, $46.0 \mathrm{~mm}$ in length,

$4643.9 \mathrm{~mm}$ in width at base, tapering to a point; dorsal scales of base of tail granular rapidly

465 becoming flatter posteriorly; and median row of transversely enlarged subcaudal scales twice as

466 wide as long not extending onto lateral margin of tail.

467 Coloration of LSUHC 13455 life (Fig. 5). Dorsal ground color of head body, and limbs light-

468 brown; dorsal ground color of tail yellow; top of head bearing large, dark-brown, round blotches

469 edged in yellow; dark-brown, wide, nuchal loop extending from posterior margin of one eye,

470 across occiput, to posterior margin of other eye; nape bearing a large, dark-brown band edged in

471 yellow with distinct paravertebral sections; five dark-brown body bands edged in yellow with

472 distinct paravertebral sections between limb insertions; one dark-brown post-sacral band edged

473 in yellow bearing a longitudinal yellow stripe; 13 dark-brown caudal bands wider than 12

474 yellow, hourglass-shaped, caudal bands with darkened centers; dorsal portion of forelimbs

475 mottled with yellow; dorsal portion of hind limbs bearing large, elliptical, dark-brown blotches

476 edges in yellow; flanks with a series of 9-11 dark-brown, round to irregularly shaped blotches

477 edged in yellow. All ventral surfaces generally beige, immaculate except for ventral surfaces of

478 forelimbs, forelegs, hands, feet, and posterior section of tail bearing dark pigment.

479 Distribution. Cyrtodactylus peguensis is known only from the type locality of Myin Mo Shwe

480 Taung Pagoda, $9.5 \mathrm{~km}$ east of the village of Hpa Lon, Bago Division, Taikkyi Township,

481 Yangon (north) District Myanmar (Fig. 1).

482 Natural History. No natural history data accompanied the description of the syntypes. LSUHC

48313455 was collected in a region composed of low foothills and highly disturbed forest (Fig. 6).

484 The specimen was collect at 2100 hours as it was crawling down an earthen bank covered with

485 small rocks $(<1 \mathrm{~m}$ in diameter) along the side of steep dirt road at the base of the Myin Mo Shwe 486 Taung Pagoda. 
487 Comparisons. We did not have access to the specimens from the Panlaung and Pyadalin Cave

488 Wildlife Sanctuary, Shan State (CAS 226142-43) or the Shwe Settaw Wildlife Sanctuary,

489 Magway Division (CAS 226139) that are illustrated in the phylogeny, and thus could not

490 compare them to Cyrtodactylus peguensis or the new species described herein. It is clear

491 however, that based on their phylogenetic relationships they are distinct from all the species

492 discussed in this report. Cyrtodactylus peguensis is differentiated from C. annandalei by the top

493 of the head being blotched as opposed to being patternless. Cyrtodactylus peguensis is most

494 closely related to $C$. pyinyaungensis (Fig. 2) but differs from it by having significantly higher

495 mean values of infralabial scales (IL; 7.0 vs. 6.0), longitudinal rows of dorsal tubercles (LRT;

49618.0 vs. 16.4), post-precloacal scales (PPS; 3.0 vs. 2.0), fourth toe lamellae (4TL; 19.0 vs 17.0),

497 and ventral scales (VS; 36.5, vs. 31.8) (Table 7, 8). Cyrtodactylus peguensis further differs from

498 the new species (see below) from Mt. Popa and the Bago Yoma by having significantly higher

499 mean value of post-precloacal scales (PPS; 3.0 vs. 2.0), and fourth toe lamellae (4TL; 19.0 vs

500 17.6) and domed to weakly conical and weakly keeled body tubercles vs. raised and moderately

501 keeled body tubercles (Table 6, 7). From the new species (see below) known only from the Myin

502 Mo Swhe Taung Pagoda, it differs by having significantly higher mean number of longitudinal

503 rows of dorsal body tubercles (LRT; 18.0 vs. 13.0) and significantly more post-precloacal scales

504 (PPS; 3.0 vs. 2.0) (Tables 7, 8). Cyrtodactylus peguensis is widely separated from $C$.

505 pyinaungensis and C. meersi sp. nov. in the PCA and DAPC analyses and shares a 3.3\% and

$50610.3 \%$ uncorrected pairwise sequence divergence, respectively, from them. It shares a 4.0-5.0\%

507 sequence divergence with C. myintkyawthurai sp. nov. (Table 3).

508 Remarks. Boulenger (1893) listed Cyrtodactylus peguensis as having nine supralabials and

509 seven or eight infralabials and Smith (1921) reports 9-11 supralabials and 7-9 infralabilas

510 whereas we report seven supralabials and infralabials in the syntype. Boulenger's and Smith's

511 totals were a result of counting all the granular scales along the labial margins posterior to the

512 enlarged labial scales which was not done here. Boulenger (1893) reports the syntypes as having

$51343-45$ ventral scales across the belly whereas we report 37 scales in the syntype between the 
514 ventrolateral folds. Boulenger (1893) did not indicate how his counts were made. Boulenger

515 (1893) states that femoral pores were absent in the syntypes, however, we counted nine femoral

516 pores on the right leg and 10 on the left. Femoral pores in species of the peguensis group are

517 difficult to see because they are small and not imbedded within enlarged femoral scales as in

518 other Cyrtodactylus. Additionally, the pores on the pore-bearing scales generally lie hidden

519 beneath the posterior edges of the scales of the scale row immediately anterior to the pore-

520 bearing row. Boulenger (1893) described the dorsal pattern as consisting of two series of large

521 dorsal spots. This is true for the syntype BMNH 1946.8.23.10 however based on his illustration

522 of the lost syntype, the spots are confluent on the midline as they are in LSUHC 13455 (Fig. 5).

523 This description was made even more confusing by Smith (1921:428) who accurately noted the

524 difference between the syntypes but providesdan illustration of a specimen of C. zebriacus from

525 southern Thailand bearing a very different color pattern which he referred to as the "Forma

526 typica".

527

528 Cyrtodactylus meersi sp. nov.

529 Bago Yoma Bent-toed Gecko

$530 \quad$ (Fig. 7)

531 urn:lsid:zoobank.org:act:172923F3-0422-4247-A5D0-38E30FE1B1C5

532

533 Holotype. Juvenile male LSUHC 13455 collected on 18 May 2017 at 2000 hrs by Mark. W.

534 Herr from Myin Mo Swhe Taung Pagoda, Bago Division, Taikkyi Township, Yangon (north)

535 District, Myanmar $\left(17.46272^{\circ} \mathrm{N}, 96.01624^{\circ} \mathrm{E}\right.$, elevation $\left.162 \mathrm{~m}\right)$

536 Diagnosis. Cyrtodactylus meersi sp. nov. differs from other species of the peguensis group by

537 having the unique combination of seven supralabials and eight infralabials; 32 paravertebral

538 tubercles; 13 longitudinal rows of body tubercles; 32 ventral scales; 17 subdigital lamellae on the

539 fourth toe; 12 femoral pores; eight precloacal pores; two rows of post-precloacal scales; and

540 domed to weakly conical and weakly keeled body tubercles (Table 7). We note however, that 
541 this diagnosis is not robust due to having only a sample size of one juvenile and will be subject

542 to adjustment if additional specimens are ever collected and analyzed. Nonetheless, the

543 placement of this individual near the base of the phylogeny (Fig. 2) and it having an uncorrected

544 percent sequence divergence of $10.0-13.7 \%$ from all other species in the phylogeny (Table 3 ) is

545 strong evidence of its species status.

546 Description of holotype. Juvenile, SVL $36.0 \mathrm{~mm}$; head moderate in length (HL/SVL 0.27), wide

547 (HW/HL 0.67), somewhat flattened (HD/HL 0.41), distinct from neck, triangular in dorsal

548 profile; lores inflated, prefrontal region concave, canthus rostralis rounded; snout elongate

549 (ES/HL 0.42), rounded in dorsal profile; eye large (ED/HL 0.27); ear opening elliptical to

550 triangular, moderate in size (EL/HL 0.09); eye to ear distance greater than diameter of eye;

551 rostral rectangular, partially divided dorsally, bordered posteriorly by large left and right

552 supranasals separated by small internasal, laterally by first supralabials; external nares bordered

553 anteriorly by rostral, dorsally by large supranasal, posteriorly by two small postnasals, ventrally

554 by first supralabial; seven $(\mathrm{R}, \mathrm{L})$ rectangular supralabials extending to below midpoint of eye;

555 eight $(\mathrm{R}, \mathrm{L})$ infralabials tapering smoothly to below posterior margin of orbit; scales of rostrum

556 and lores flat, larger than granular scales on top of head and occiput; scales on top of head and

557 occiput intermixed with slightly enlarged tubercles; dorsal supraciliaries not elongate or keeled;

558 mental triangular, bordered laterally by first infralabials and posteriorly by large, left and right

559 trapezoidal postmentals that contact medially for $60 \%$ of their length posterior to mental; one

560 row of slightly enlarged chinshields extending posteriorly to fourth infralabial; and gular and

561 throat scales small, granular, grading posteriorly into larger, flatter, smooth, subimbricate to

562 imbricate, pectoral and ventral scales.

563 Body relatively short (AG/SVL 0.45) with weak ventrolateral folds; dorsal scales small,

564 interspersed with small, domed to weakly conical, semi-regularly arranged weakly keeled

565 tubercles; tubercles extend from occiput onto base of tail but no farther; tubercles on occiput and

566 nape small, those on posterior portion of body larger and keeled; approximately 13 longitudinal

567 rows of dorsal tubercles; 32 paravertebral tubercles; approximately 32 flat, imbricate, ventral 
568

569

570

571

572

573

574

575

576

577

578

579

580

581

582

583

584

585

586

587

588

589

590

591

592

593

594

scales larger than dorsal scales; eight pore-bearing precloacal scales; two rows of large postprecloacal scales; and no deep precloacal groove or depression.

Forelimbs moderate in stature, relatively short (FL/SVL 0.13); flat scales of forearm larger than those on body, not interspersed with tubercles; palmar scales rounded, slightly raised; digits well-developed, relatively short, inflected at basal, interphalangeal joints; digits slightly narrower distal to inflections; claws well-developed, sheathed by a dorsal and ventral scale; hind limbs more robust than forelimbs, moderate in length (TBL/SVL 0.17 ), covered dorsally by granular scales interspersed with slightly larger, weakly keeled tubercles and anteriorly by large, flat, imbricate scales; ventral scales of femora flat, imbricate, larger than dorsals, lacking a row of enlarged femoral scales; six (R,L) weakly developed, pore-bearing femoral scales; small postfemoral scales form an abrupt union with large, flat ventral scales of posteroventral margin of thigh; subtibial scales flat, imbricate; plantar scales flat but slightly raised; digits relatively short, well-developed, inflected at basal, interphalangeal joints; 17 subdigital lamellae on fourth toe; and claws well-developed, base of claw sheathed by a dorsal and ventral scale; two enlarged postcloacal tubercles at base of tail; and postcloacal scales flat

Original tail moderate in proportions, $38.0 \mathrm{~mm}$ in length, $3.6 \mathrm{~mm}$ in width at base, tapering to a point; dorsal scales of base of tail granular rapidly becoming flatter posteriorly; and median row of transversely enlarged subcaudal scales twice as wide as long, not extending onto lateral margin of tail.

Coloration in life (Fig. 7). Dorsal ground color of head body, limbs, and tail straw-colored; top of head bearing small, dark-brown spots, those in center of head well-defined and edged in yellow; dark-brown, wide, nuchal loop extending from posterior margin of one eye, across occiput, to posterior margin of other eye; three large, dark-brown spots edged in yellow on nape; five dorsal bands between limb insertions; anteriormost band composed of the three transversely arranged, dark-brown blotches edged in yellow; remaining bands composed of paired, separate, paravertebral, dark-brown blotches edged in yellow; postsacral band composed of three, darkbrown blotches edge in yellow; dorsal surface of limbs mottled with yellow spots and larger, 
595 poorly defined, dark blotches; 13 dark bands on tail, anteriormost bifurcated medially; 13 light596 colored, yellowish bands on tail; tail-tip white; flanks bearing 8-10 small, diffuse, dark spots. All

597 ventral surfaces generally beige, immaculate except for ventral surfaces of forelimbs, forelegs,

598 hands, feet, and posterior section of tail bearing dark pigment. Based on ontegenetic changes in 599 color pattern observed in Cyrtodactylus pyinyaungensis, it is likely that with an increase in SVL, 600 blotches on the flanks and the top of the head would become slightly larger and more defined.

601 Distribution. Cyrtodactylus meersi sp. nov. is known only from the type locality of Myin Mo 602 Shwe Taung Pagoda, $9.5 \mathrm{~km}$ east of the village of Hpa Lon, Bago Division, Taikkyi Township, 603 Yangon (north) District Myanmar (Fig. 1).

604 Etymology. The specific epithet, meersi, is named in honor of Mr. John Meers whose generous 605 private donations to Fauna \& Flora International's in the name of karst conservation have 606 resulted in the continuation of karst biology research in Indochina.

607 Natural History. The holotype was collected in a region composed of low foothills and highly 608 disturbed forest (Fig. 6). The specimen was encountered at 2000 hours as it was sitting in the 609 middle of an ant trail, presumably preying on the ants. The fact that the specimen is a juvenile 610 suggests the reproductive season is prior to May.

611 Comparisons. Cyrtodactylus meersi sp. nov. is differentiated from C. annandalei by the top of 612 the head being blotched as opposed to being patternless. Differences between C. meersi sp. nov. 613 and C. peguensis are reported in the comparisons section of the latter. Cyrtodactylus meersi sp. 614 nov. differs from C. pyinyaungensis in having significantly higher mean number of infralabial 615 scales (IL; 8.0 vs. 6.0), fourth toe lamellae (4TL; 17.0 vs 15.0), and having domed to weakly 616 conical and weakly keeled body tubercles vs. raised and moderately keeled body tubercles 617 (Tables 7, 8). It differs from the new species (see below) from Mt. Popa and the Bago Yoma by 618 having significantly higher mean number of infralabial scales (IL; 8.0 vs. 6.5) and a significantly 619 lower mean number of longitudinal rows of dorsal tubercles (LRT; 13 vs. 18.6). Cyrtodactylus 620 meersi sp. nov. is widely separated from all other species in both the PCA and DAPC and does 
621 not fall within the plot distribution of any other species. Additionally, Cyrtodactylus meersi sp.

622 nov. has an uncorrected pairwise sequence divergence from them of 10-13.7\% (Table 3).

623 Remarks. Some (i.e. Dayrat, 2005) have criticized descriptions of new species based on only a

624 single specimen and posit that this should 'never' be done because such a description cannot take

625 into account intraspecific variation that could potentially preclude its specific recognition. We

626 are concerned about describing a new species based on a single juvenile specimen but only

627 because the diagnosis is incomplete, not because the diagnosis has anything to do with the reality

628 of this specimen representing a distinct independently evolving lineage. Such a notion is false

629 and a conflation of the species' ontology with its epistemology (Frost and Kluge, 1994).

630 Undoubtedly, additional specimens will expand and improve the diagnosis, however, because of

631 safety concerns we cannot return to the type locality which is now also being converted to

632 agriculture land. Thus, we felt it prudent to describe this species for potential protective status as

633 soon as possible rather than delay its publication for the sake of a better diagnosis. The weak part

634 of recognizing this specimen as a distinct species is not the incomplete diagnosis, but that the

635 species is being delimited on the basis of a single-locus mtDNA phylogeny. It is well-

636 documented that mtDNA phylogenies can reveal significant structure in a data set by recovering

637 sequentially nested monophyletic groups even though within that same data set, nuclear genes

638 can indicate significant gene flow among these groups (e.g. Shaw, 2002; Fisher-Reid \& Wiens,

639 2011; Toews \& Brelsford, 2012), thus precluding their species status. This weakens any

640 hypothesis of specific identity based solely on mtDNA data. Nonetheless, given the current data

641 available concerning its phylogenetic relationships and the significant and discrete

642 morphological and color pattern differences separating C. meersi sp. nov. from its congeners, we

643 regard the specific identity of $C$. meersi sp. nov. as a testable hypothesis.

644

645 Cyrtodactylus myintkyawthurai sp. nov.

646 Mt. Popa Bent-toed Gecko

647 (Fig. 8) 
648 649 650 651

652 653

urn:1sid:zoobank.org:act:6B634A60-C1C5-492F-9AF8-5E2FD62D137C

Cyrtodactylus fea Wood et al., 2012:995; Agarwal et al., 2014:147; Brennan et al., 2017:3.

Holotype. Adult male LSUHC 13808 collected on 27 October 2017 at 1030 hrs by Evan S. H. Quah, Perry L. Wood, Jr., Matthew L. Murdoch, Myint Kyaw Thura, Aung Lin, Robert E. Espinoza, Tun Oo, and L. Lee Grismer from Taung Twin Chaung camp, Mt. Popa, Kyauk-pataung Township, Mandalay Division, Myanmar $\left(20.93087^{\circ} \mathrm{N}, 95.22580^{\circ} \mathrm{E} ; 978 \mathrm{~m}\right.$ in elevation). Paratypes. LSUHC 13500-02, 13505, 13806-07, 13809 bear the same collection data as the holotype. CAS 245200-03 collected on 1 August 2007 by A.K. Shein, S.W. Kyi, and J.V. Vindum from Central Bago Yoma Range, between Pallan Gyi Forest Camp and summit, Bago Division, Myamnar $\left(18.92108^{\circ} \mathrm{N}, 95.814027^{\circ} \mathrm{E}, 268 \mathrm{~m}\right)$. CAS 222147 collected on 11 August 2001 by H. Win and A.K. Shein from the Kyetshar Elephant Camp, Kyet Shar Village, Aok Twin Township, Bago Division, Myanmar $\left(18.88094^{\circ} \mathrm{N}, 96.07922^{\circ} \mathrm{E}, 263\right.$ m elevation). CAS 222128 collected on 31 July 2001 by H. Win, A.K. Shein and H. Tun from the Ka Baung Reserve, Aok Twin Township, Taung Oo District, Bago Division, Myanmar $\left(18.834750^{\circ} \mathrm{N}\right.$, $96.18638^{\circ} \mathrm{E}, 160 \mathrm{~m}$ elevation).

Diagnosis. Cyrtodactylus myintkyawthurai sp. nov. differs from other species in the peguensis group by having the unique combination of six or seven supralabials and six or seven infralabials; 28-33 paravertebral tubercles; 17-23 longitudinal rows of body tubercles; 32-36 ventral scales; 17-19 subdigital lamellae on the fourth toe; $12-20$ femoral pores in males; 7-9 precloacal pores in males; two rows of post-precloacal scales; raised, moderately to strongly keeled body tubercles; and a maximum SVL of $75.1 \mathrm{~mm}$ (Table 7).

Description of holotype. Adult male, SVL $57.6 \mathrm{~mm}$; head moderate in length (HL/SVL 0.28), wide (HW/HL 0.70), somewhat flattened (HD/HL 0.43), distinct from neck, triangular in dorsal profile; lores inflated, prefrontal region concave, canthus rostralis rounded; snout elongate (ES/HL 0.40), rounded in dorsal profile; eye large (ED/HL 0.27); ear opening triangular, 
675 moderate in size (EL/HL 0.13); eye to ear distance greater than diameter of eye; rostral 676 rectangular, partially divided dorsally, bordered posteriorly by large left and right supranasals

677 separated an internasal, laterally by first supralabials; external nares bordered anteriorly by

678 rostral, dorsally by large supranasal, posteriorly by two postnasals, ventrally by first supralabial;

679 six $(\mathrm{R}, \mathrm{L})$ rectangular supralabials extending to below midpoint of eye; six (R,L) infralabials

680 tapering smoothly to below posterior margin of orbit; scales of rostrum and lores flat, larger than

681 granular scales on top of head and occiput; scales on top of head and occiput intermixed with

682 slightly enlarged tubercles; dorsal supraciliaries not elongate or keeled; mental triangular,

683 bordered laterally by first infralabials and posteriorly by large, left and right trapezoidal

684 postmentals that contact medially for $60 \%$ of their length posterior to mental; one row of slightly

685 enlarged chinshields extending posteriorly to third infralabial; and gular and throat scales small,

686 granular, grading posteriorly into larger, flatter, smooth, subimbricate to imbricate, pectoral and

687 ventral scales.

688 Body relatively short (AG/SVL 0.47) with weak ventrolateral folds; dorsal scales small,

689 interspersed with larger, moderately to strongly keeled, semi-regularly arranged keeled tubercles;

690 tubercles extend from occiput onto base of tail but no farther; tubercles on occiput and nape

691 smaller than those on posterior portion of body that are larger and keeled; approximately 17

692 longitudinal rows of dorsal tubercles; 31 paravertebral tubercles; approximately 35 flat,

693 imbricate, ventral scales larger than dorsal scales; seven pore-bearing precloacal scales; two rows

694 of large post-precloacal scales; and no deep precloacal groove or depression.

Forelimbs moderate in stature, relatively short (FL/SVL 0.16); flat scales of forearm

696 larger than those on body, not interspersed with tubercles; palmar scales raised; digits slightly

697 narrower distal to inflections; claws well-developed, sheathed by a dorsal and ventral scale; hind

698 limbs more robust than forelimbs, moderate in length (TBL/SVL 0.15), covered dorsally by

699 granular scales interspersed with slightly larger, weakly keeled tubercles and anteriorly by large,

700 flat, imbricate scales; ventral scales of femora flat, imbricate, larger than dorsals, lacking a row

701 of enlarged femoral scales; six $(\mathrm{R}, \mathrm{L})$ pore-bearing femoral scales; small postfemoral scales form 
702 an abrupt union with large, flat ventral scales of posteroventral margin of thigh; subtibial scales

703 flat, imbricate; plantar scales raised; digits relatively short, well-developed, inflected at basal,

704 interphalangeal joints; 17 subdigital lamellae on fourth toe; and claws well-developed, base of

705 claw sheathed by a dorsal and ventral scale; two enlarged postcloacal tubercles at base of tail;

706 and postcloacal scales flat.

707 Original tail moderate in proportions, $64.0 \mathrm{~mm}$ in length, $5.9 \mathrm{~mm}$ in width at base,

708 tapering to a point; dorsal scales of base of tail granular rapidly becoming flatter posteriorly; and

709 intermittent rows of transversely enlarged, median, subcaudal scales twice as wide as long, not

710 extending onto lateral margin of tail.

711 Coloration in life (Fig. 8). Dorsal ground color of head body, limbs, and tail yellow; top of head

712 bearing large, dark-brown, irregularly shaped blotches edged in yellow; dark-brown, wide,

713 nuchal loop extending from posterior margin of one eye, across occiput, to posterior margin of

714 other eye; nape bearing a large, dark-brown band edged in yellow; four wide, dark-brown body

715 bands between limb insertions edged in yellow with paravertebral sections; one dark-brown post-

716 sacral band edged in yellow bearing paravertebral sections; 10 dark-brown caudal bands wider

717 than 11 yellow, caudal bands with darkened centers; dorsal portion of forelimbs darkly banded;

718 dorsal portion of hind limbs bearing irregularly shaped, dark-brown blotches edges in yellow;

719 flanks with a series of 8-10 dark-brown, round to irregularly shaped blotches of varying sizes

720 edged in yellow. All ventral surfaces generally beige, immaculate except for ventral surfaces of

721 forelimbs, forelegs, hands, feet, and posterior section of tail bearing dark pigment.

722 Variation. Variation in the paratypes of Cyrtodactylus myintkyawthurai sp. nov. is most notable

723 in the dorsal banding pattern. Specimens from the central Bago Yoma Range tend to have dorsal

724 bands that are divided along the midline, thus manifesting distinct paravertebral elements (CAS

725 222147, 245201-03) although this is not so evident in CAS 245200 and CAS 222128 has

726 somewhat of an anomolus pattern with some elongate, irregularly shape blotches. The banding

727 pattern in specimens from Mt Popa lacks complete midline bifurcation although the dorsal bands

728 have distinct paravertebral elements. The dorsal bands of all the paratypes except CAS 245200 
729 and 245203, LSUHC 13505 are relatively wider than those of the holotype LSUHC 13808.

730 Specimens CAS 245200, 245202 and LSUHC 13500-02, 13806, and 13809 have regenerated

731 tails bearing dark mottling. Specimens CAS 222128 and LSUHC 13505 have broken tails. Adult

732 females have dimpled scales or 0-8 femoral pores. Other meristic mensural variation in the type

733 series is presented in Table 6.

734 Distribution. Cyrtodactylus myintkyawthurai sp. nov. ranges throughout Mt. Popa, Mandalay

735 Division and the central section of the Bago Yoma Range, Bago Division (Fig. 2).

736 Etymology. The specific epithet, myintkyawthurai, is a patronym honoring Myint Kyaw Thura

737 for his contributions to the study of herpetology in Myanmar, his discovery of several new

738 species, and collaboration with foreign researchers.

739 Natural History. At both Mt. Popa and in the central Bago Yoma Range, Cyrtodactylus

740 myintkyawthurai sp. nov. occurs in hilly regions covered in deciduous dipterocarp forest up to

$741978 \mathrm{~m}$ in elevation (Fig. 9). The Mt. Popa specimens were collected at night from $0.05-1 \mathrm{~m}$

742 above the ground on rocks, the trunks of small trees, on leaves or on the ground amongst small

743 rocks.

744 Comparisons. See previous comparison sections.

745

746 DISCUSSION

747 Members of the peguensis group all appear to be habitat generalists within the hilly regions they

748 inhabit. Cyrtodactylus pyinyaungensis have been found crawling on karst boulders in dry

749 secondary forest as well as highly disturbed, burned over lowland forests/agricultural areas.

750 Cyrtodactylus myintkwawthurai sp. nov. is know from dry deciduous forests and mixed

751 dipterocarp forests and C. meersi sp. nov. and C. peguensis occur in highly disturbed lowland

752 forests bordering agricultural fields. No natural history data were provided with the description

753 of C. annandalei. This lack of microhabitat preference suggests that additional populations of

754 this species group are very likely to be found in other hilly areas both within and along the 
755 fringes of the Ayeyarwady Basin. It also indicates that agricultural practices in these areas should 756 be monitored for purposes of conservation.

757 The rapidly growing awareness of the diversity of karst-associated species of

758 Cyrtodactylus and other gekkonids in Myanmar (Grismer et al., 2017a,b, 2018a,b) mirrors that

759 in other Southeast Asian nations (see discussions in Grismer et al., 2016a,b,c; Wood et al., 2017)

760 but is in no way surprising given Myanmar's vast regions of unexplored karstic habitats. What is

761 surprising, however, is the diversity within lineages restricted to the relatively featureless

762 Ayeyarwady Basin. The peguensis group collectively account for at least seven species of a

763 monophyletic group that ranges disjunctly from the eastern foothills of the Chin Hills along the

764 western fringe of the Ayeyarwady Basin to the western foothills of the Shan Hills along the

765 eastern fringe of the basin (Fig. 1). Additionally, the low hills of the centrally located Bago

766 Yoma are inhabited by C. peguensis, C. myintkyawthurai sp. nov., and C. meersi sp. nov. The

767 allopatric distribution of these species is likely due to range fragmentation resulting from

768 sedimentation from the numerous river courses - the Ayeyarwady and Sittaung being the

769 largest - since at least the Lower Miocene-Upper Pliocene (Agarwal et al., 2014). The other

770 eight species found within the Ayeyarwady Basin or along its mountainous fringes that are not

771 part of the peguensis group (Bauer, 2003; Mahoney, 2009) and are not monophyletic but nested

772 within lineages containing Indian, Bangladeshi, and Himalayan taxa from farther west, indicating

773 that colonization of the Ayeyarwady Basin is the result of multiple invasions since at least the

774 Upper Miocene (Agarwal et al., 2014).

775

776 CONCLUSIONS

777 A phylogenetic taxonomy of species in the Cyrtodactylus peguensis group from the Ayeyarwady

778 Basin of Myanmar recovers at least seven species, four of which are undescribed. Three species,

779 including $C$. peguensis occur in the low hills of the Bago Yoma mountain range one of which, $C$.

780 meersi sp. nov., is syntopic with $C$. peguensis. As more lowland hilly areas associated with the

781 Ayeyarwady Basin are surveyed, more new species of this group are likely to be discovered. 
782 These discoveries continue the recent surge of descriptions of new species of Cyrtodactylus that 783 are being discovered in Myanmar.

784

785

786

787

788

789

790

791

792

793

794

795

796

797

798

799

800

801

802

803

804

805

806

\section{ACKNOWLEDGEMENTS}

We wish to thank Mr. Win Naing Thaw of the Ministry of natural Resources and Environmental Conservation Forest Department for the collection and export permits. We thank the staff of the Shwe Gue Gu Hotel and Genious Coffee for their hospitality.

\section{New Species Registration}

The following information was supplied regarding the registration of a newly described species: to be completed after acceptance of the manuscript.

Publication ID:

urn:1sid:zoobank.org:author:Xxxxxxxx

urn:1sid:zoobank.org:act:xxxxxx

\section{REFERENCES}

Acinas SG, Klepac-Ceraj V, Hunt DE, Pharino C, Ceraj I, Distel DL, Polz MF. 2004. Finescale phylogenetic architecture of a complex bacterial community. Nature 430: 551-554 https://doi.org/10.1038/nature02649

Agarawal I, Bauer AM, Jackman TR, Karanth KP. 2014. Insights into Himalayan biogeography from geckos: a molecular phylogeny of Cyrtodactylus (Squamata: Gekkonidae). Molecular Phylogenetics and Evolution 80:145-155.

Annandale N. 1913. The Indian geckos of the genus Gymnodactylus. Records of the Indian Museum 9:309-326. 
807 Barraclough TG, Birky CW, Jr, Burt A. 2003. Diversification in sexual and asexual

808

809

810

811

812

813

814

815

816

817

818

819

820

821

822

823

824

825

826

827

828

829

830

831

832

organisms. Evolution 57: 2166-2172. https://doi.org/10.1554/02-339

Bauer AM. 2003. Descriptions of seven new Cyrtodactylus (Squamata: Gekkonidae) with a key to the species of Myanmar (Burma). Proceedings of the California Academy of Sciences 54:463-498.

Boulenger GA. 1893. Concluding report on the reptiles and batrachians obtained in Burma by Signor L. Fea, dealing with the collection made in Pegu and the Karin Hills in 1887-88. Annali del Museo civico di storia naturale di Genova 2:304-345.

Boulenger GA. 1912. A vertebrate fauna of the Malay Peninsula from the Isthmus of Kra to Singapore incl. the adjacent islands. Reptilia and Amphibia. London (Taylor \& Francis), xiii $+298 \mathrm{~S}$.

Brennan IG, Bauer AB, Ngo VT, Wang Y-y, Wen-zhi W, Zhang Y-P, Murphy RW. 2017. Barcoding utility in a mega-diverse, cross-continental genus: keeping pace with Cyrtodactylus geckos. Scientific Reports 7:1-11. DOI:10.1038/s41598-017-05261-9

Cangelosi R, Goriely A. 2007. Component retition in principal component analysis with application to cDNA microarray data. Biology Direct 2007 2:1-21 DOI:10.1186/1745$6150-2-2$

Chan-ard T, Grossmann W. Gumprecht A, Schulz KD. 1999. Amphibians and reptiles of peninsular Malaysia and Thailand - An illustrated checklist [bilingual English and German]. Bushmaster Publications, Würselen, Gemany, 240 pp.

Chan-ard T, Parr JWK. Nabhitabhata J. 2015. A field guide to the reptiles of Thailand. Oxford University Press, NY, 352 pp.

Connette GM, Oswald P, Thura MK, Connette KJL, Grindley ME, Songer M, Zug GR, Mulchay DG. 2017. Rapid forest clearing in a Myanmar proposed national park threatens two newly discovered species of geckos (Gekkonidae: Cyrtodactylus). PLoS One 12: e0174432. 
833 Cox MJ, Van Dijk PP, Nabhitabhata J, Thirakhuptn xx, Kumthorn x. 1998. A Photographic

Guide to Snakes and Other Reptiles of Peninsular Malaysia, Singapore and Thailand.

835 Ralph Curtis Publishing, 144 pp.

836 Coyne JA, Orr HA. 1998. The evolutionary genetics of speciation. Philosophical Transactions of the Royal Society of London B 353: 287-305. doi: 0.1098/rstb.1998.0210

838

839

840

Das I. 2010. A Field Guide to the Reptiles of South-East Asia. Bloomsbury, New York. 376 pp.

De Queiroz K. 2007. Species concepts and species delimitation. Systemtic Biology 56: 879-886. https://doi.org/10.1080/10635150701701083

841 Denzer W, Manthey U. 1991. A nominal checklist of the lizards inhabiting in Peninsular 842 Malaysia and Singapore. Raffles Bulletin of Zoology 39:309-322.

843 Fea L. 1897. Viaggio di Leonardo Fea in Birmania e regioni vicine. LXXVI. Riassunto generale 844 dei risultati zoologici. Annali del Museo Civico di Storia Naturale di Genova, Series 2, $845 \quad 42: 383-660$.

846 Feulner PGD, Kirschbaum F, Mamonekene V, Ketmaier V, Tiedemann R. 2007. Adaptive 847 radiation in African weakly electric fish (Teleostei: Mormyridae: Campylomormyrus): a combined molecular and morphological approach. Journal of Evolutionary Biology 20: 403-414. doi: $\underline{10.1111 / \mathrm{j} .1420-9101.2006 .01181 . \mathrm{x}}$

Fisher-Reid MC \& Wiens JJ. 2011. What are the consequences of combining nuclear and mitochondrial data for phylogenetic analysis? Lessons from Plethodon salamanders and

Fujisawa T \& Barraclough TG. 2013. Delimiting species using single-locus data and the 855 Generalized Mixed Yule Coalescent approach: a revised method and evaluation on simulated data sets. Systematic Biology 62: 707-724. doi:10.1093/sysbio/syt033 
857 Fontaneto D, Herniou EA, Boschetti C, Caprioli M, Melone G, Ricci C, Barraclough TG.

858 2007. Independently evolving species in asexual bdelloid rotifers. PLoS Biol. 5(4): e87.

859 https://doi.org/10.1371/journal.pbio.0050087

860 Frost DR \& Kluge AG. 1994. A consideration of espistemology in systematic biology, with

$861 \quad$ special reference to species. Cladistics 10:259-294.

$862 \quad$ http://dx.doi.org/10.1111/j.1096-0031.1994.tb00178.x

863 Grismer LL, Wood Jr. PL, Anuar S, Davis HR, Cobos AJ, Murdoch ML. 2016a. A new

864 species of karst forest Bent-toed Gecko (genus Cyrtodactylus Gray) not yet threatened by

865 foreign cement companies and a summary of Peninsular Malaysia's endemic karst forest

866 herpetofauna and the need for its conservation. Zootaxa 4061:1-17.

867 Grismer LL, Wood Jr. PL, Anuar S, Grismer MS, Quah ES, Murdoch ML, Muin MA,

868 Davis HR, Aguilar C, Klaback R, Cobos AJ, Aowphol A, Sites Jr. JW. 2016b. Two

869 new Bent-toed Geckos of the Cyrtodactylus pulchellus complex from Peninsular

$870 \quad$ Malaysia and multiple instances of convergent adaptation to limestone forest ecosystems.

$871 \quad$ Zootaxa 4105:401-429.

872 Grismer LL, Wood Jr., PL, Aowphol A, Cota M, Grismer MS, Murdoch M, Aguilar C,

873 Grismer JL. 2016c. Out of Borneo, again and again: biogeography of the Stream Toad

874 genus Ansonia Stoliczka (Anura: Bufonidae) and the discovery of the first limestone

875 cave-dwelling species. Biological Journal of the Linnean Society 120:371-395.

876 Grismer LL, Wood Jr, PL, Thura MK, Zin T, Quah ESH, Murdoch ML, Grismer MS, Lin

877 A, Kyaw H \& Ngwe L. 2017a. Twelve new species of Cyrtodactylus Gray (Squamata:

878 Gekkonidae) from isolated limestone habitats in east-central and southern Myanmar

879 demonstrate high localized diversity and unprecedented microendemism. Zoological

$880 \quad$ Journal of the Linnean Society 182:862-959.

881 Grismer LL, Wood Jr, PL, Thura MK, Zin T, Quah ESH, Murdoch ML, Grismer MS, Lin 
882

883

884

885

886

887

888
A, Kyaw H \& Ngwe L. 2017b. Phylogenetic taxonomy of Hemiphyllodactylus Bleeker, 1860 (Squamata: Gekkonidae) with descriptions of three new species from Myanmar. Journal of Natural History https://doi.org/10.1080/00222933.2017.1367045

Grismer LL, Wood Jr, PL, Myint Kyaw Thura, Zin T, Quah ESH, Murdoch ML, Grismer MS, Aung Lin, Htet Kyaw. 2018a. Three more new species of Cyrtodactylus (Squamata: Gekkonidae) from the Salween Basin of eastern Myanmar underscores the urgent need for the conservation of karst habitats. Journal of Natural History in press.

Grismer LL, Wood Jr, PL, Thura MK, Zin T, Quah ESH, Grismer MS, Murdoch ML, Espinoza, RE, Aung Lin. 2018b. A new Cyrtodactylus Gray (Squamata, Gekkonidae) from the Shan Hills and the biogeography of Bent-toed Geckos from eastern Myanmar. Zootaxa in press.

Guindon S, Dufayard J-F, Lefort V, Anisimova M, Hordijk W, Gascuel O. 2010. New algorithms and methods to estimate maximum-likelihood phylogenies: Assessing the Performance of PhyML 3.0. Systematic Biology 59: 307-321. https://doi.org/10.1093/sysbio/syq010

Hoang DT, Chernomor O, von Haeseler A, Minh BQ, Le SV. 2017. UFBoot2: Improving the Ultrafast Bootstrap Approximation. Moloecular Biology and Evolution 35:518-522. https://doi.org/10.1093/molbev/msx281

Huelsenbeck JP, Ronquist F, Nielsen R, Bollback JP. 2001. Bayesian Inference of phylogeny and its impact on evolutionary biology. Science 294:2310-2314. DOI: 10.1126/science.1065889.

Jombart T, Devillard S, Balloux F. 2010. Discriminant analysis of principal components: a new method for the analysis of genetically structured populations. BMC Genetics 11-94. https://doi.org/10.1186/1471-2156-11-94 
906 Katoh M, Kuma M. 2002. MAFTT: a novel method for rapid sequence alignment based on fast

907

908

909

910

911

912

913

914

915

916

917

918

919

920

921

922

923

924

925

926

927

928

929

930 Fourier transform. Nucleic Acids Research 30:3059-3066. https://doi.org/10.1093/nar/gkf436

Kearse M, Moir R, Wilson A, Stones-Havas S, Cheung M, Sturrock S, Buxton S, Cooper A, Markowitz S, Duran C, Thierer T, Ashton B, Meintjes P, Drummond A. 2012. Geneious Basic: an integrated and extendable desktop software platform for the organization and analysis of sequence data. Bioinformatics 28:1647-1649. https://doi.org/10.1093/bioinformatics/bts199

Knowles LL, Carstens BC. 2007. Delimiting species without monophyletic gene trees. Systematic Biology 56:887-895. https://doi.org/10.1080/10635150701701091

Kumar S, Stecher G, Tamura K. 2016. MEGA7: Molecular evolutionary genetics analaysis version 7.0 for bigger datasets. Molecular Biology and Evolution 33:1870-1874. https://doi.org/10.1093/molbev/msw054

Laidlaw FF. 1901. List of a collection of snakes, crocodiles, and chelonians from the Malay Peninsula, made by members of the "Skeat Expedition," 1899-1900. Proceedings of the Zoological Society of London 2:575-583.

Leaché AD, Koo MS, Spencer CL, Papenfuss TJ, Fisher RN, McGuire JA. 2009. Quantifying ecological, morphological, and genetic variation to delimit species in the coast horned lizard species complex (Phrynosoma). Proc. Natl. Acad. Sci. USA 106:12418-12423. https://doi: 10.1073/pnas.0906380106

Maddison WP, Maddison DR. 2015. Mesquite: a modular system for evolutionary analysis. Version 3.04. Available at: http://mesquiteproject.org

Macey JJ, Larson A, Ananjeva NB, Fang Z, Papenfuss TJ. 1997. Two novel gene orders and the role of light-strand replication in rearrangement of the vertebrate mitochondrial 
931

932

933

934

935

936

937

938

939

940

941

942

943

944

945

946

947

948

949

950

951

952

953

954

955

956

genome. Molecular Biology and Evolution 14:91-

104. https://doi.org/10.1093/oxfordjournals.molbev.a025706

Mahony S. 2009. Taxonomic status of Cyrtodactylus khasiensis tamaiensis (Smith, 1940) and description of a new species allied to C. chrysopylos Bauer, 2003 from Myanmar (Reptilia: Gekkonidae). Hamadryad 34: 62-74.

Manthey U, Grossmann W. 1997. Amphibien \& Reptilien Südostasiens. Natur und Tier Verlag (Münster). Natur und Tier, Verlag. 512 pp.

Miller MA, Pfeiffer W, Schwartz T. 2010. Creating the CIPRES Science Gateway for inference of large phylogenetic trees. In: Proceedings of the Gateway Computing Environments Workshop (GCE), 14 November 2010, New Orleans, LA pp. 1-8. DOI: $\underline{10.1109 / G C E .2010 .5676129}$

Nguyen L-T, Schmidt HA, von Haeseler A, Minh BQ. 2015. IQ-TREE: A fast and effective stochastic algorithm for estimating maximum likelihood phylogenies. Molecular Biology and Evolution 32:268-274. https://doi.org/10.1093/molbev/msu300

Pianka ER, Vitt LJ. 2003. Lizards - Windows to the Evolution of Diversity. University of California Press, Berkeley, 347 pp.

Pons J, Barraclough TG, Gomez-Zurita J, Cardoso A, Duran DP, Hazell S, Kamoun S, Sumlin WD, Vogler AP. 2006. Sequence-Based Species Delimitation for the DNA Taxonomy of Undescribed Insects. Systematic Biology 55:595-609. https://doi.org/10.1080/10635150600852011

R Core Team. 2015. R: A language and environment for statistical computing. $\mathrm{R}$ Foundation for Statistical Computing. Vienna. [accessed 2016]. http://www.R-project.org

Rambaut A, Suchard MA, Xie D, Drummond AJ. 2014. Tracer v1.6. Available from: http://beast.bio.ed.ac.uk/Tracer.

Ronquist F, Teslenko M, van der Mark P, Ayres DL, Darling A, Höhna B, Larget L, Liu L, Suchard MA, Huelsenbeck JP. 2012. Mr. Bayes 3.2: efficient Bayesian phylogenetic 
957

958

959

960

961

962

963

964

965

966

967

968

969

970

971

972

973

974

975

976

977

978

979

980

981

982

983

inference and model choice across a large model space. Systematic Biology 61: 539-542. https://doi.org/10.1093/sysbio/sys029

Rösler H. 2000. Kommentierte Liste der rezent, subrezent und fossil bekannten Geckotaxa (Reptilia: Gekkonomorpha). Gekkota 2:28-153.

Sabaj MH. 2016. Standard symbolic codes for institutional resource collections in herpetology and ichthyology: an Online Reference. Version 6.5 (16 August 2016). Electronically accessible at http://www.asih.org/, American Society of Ichthyologists and Herpetologists, Washington, DC.

Shaw KL. 2012. Conflict between nuclear and mitochondrial DND phylogenies of a recent species radiation: what DNA reveals and conceals about modes of speciation in Hawaiian crickets. Proceedings of the National Academy of Sciences 99:16122-16127. https://doi.org/10.1073/pnas.242585899

Smith MA. 1916. A list of the crocodiles, tortoises, turtles and lizards at present known to inhabit Siam. Journal of the Natural History Society of Siam 2:4857.

Smith MA. 1921. New or little-know reptiles and batrachians from Southern Annam (IndoChina). Proceedings of the Zoological Society of London 1921:423-440.

Smith MA 1930. The Reptilia and Amphibia of the Malay Peninsula fromt he Isthmus of Kra to Singapore, including the adjacent Islands. A Supplement to G.A. Boulenger's Reptilia and Batrachia 1912. Bulletin of the Raffles Museum 3:1-149.

Smith MA. 1935. Fauna of British India, including Ceylon and Burma. Reptilia and Amphibia. Vol. II Sauria. London: Taylor \& Francis Ltd.

Sukumaran J. \& Knowles LL. 2017. Multispecies coalescent delimits structure, not species. Proceedings of the National Academy of Sciences 114:1607-1612. https://doi:10.1073/pnas.1607921114

Taylor EH. 1962. New oriental reptiles. University of Kansas Science Bulletin 43:209-263. Taylor EH. 1963. The lizards of Thailand. University of Kansas Science Bulletin 44: 687-1077. 
984 Toews DPL J. \& Brelsford A. 2012. The biogeography of nuclear discordance in animals.

985

986

987

988

989

990

991

992

993

994

995

996

997

998

999

1000

1001 Molecular Ecology 21:3907-3930. https://doi.org/10.1111/j.1365-294x.2012.05664.X

Uetz P, Freed, P. Hošek J. (eds.) 2018. The Reptile Database, http://www.reptile-database.org, accessed, 5 April 2018.

Ulber T, Schäfer C. 1989. Cyrtodactylus peguensis (BOULENGER, 1893). Sauria 11:145-148

Wermuth H. 1965. Liste der rezenten Amphibien und Reptilien, Gekkonidae, Pygopodidae, Xantusiidae. Das Tierreich 80. Walter de Gruyter, Berlin, Germany.

Wilcox TP, Zwickl DJ, Heath TA, Hillis DM. 2002. Phylogenetic relationships of the Dwarf Boas and a comparison of Bayesian and bootstrap measures of phylogenetic support. Molecular Phylogenetics and Evolution 25:361-371. https://doi.org/10.1016/S10557903(02)00244-0

Wood Jr. PL, Grismer LL, Aowphol A, Aguilar CA, Cota M, Grismer MS, Murdoch ML, Sites Jr. JW. 2017. Three new karst-dwelling Cnemaspis Strauch, 1887 (Squamata; Gekkoniade) from peninsular Thailand and the phylogenetic placement of $C$. punctatonuchalis and C. vandeventeri. PeerJ, DOI 10.7717/peerj.2884.

Wood Jr, PL, Jr, Heinicke MP. Jackman TR. Bauer AM. 2012. Phylogeny of bent-toed geckos (Cyrtodactylus) reveals a west to east pattern of diversification. Molecular Phylogenetics and Evolution 65: 992-1003. 
1002 


\section{Figure 1}

Distribution map of the Cyrtodactylus peguensis group.

Distribution of the species of the Cyrtodactylus peguensis group in the Ayeyarwady Basin and the adjacent foothills of the Chin Hills and Shan Hills in Myanmar. 


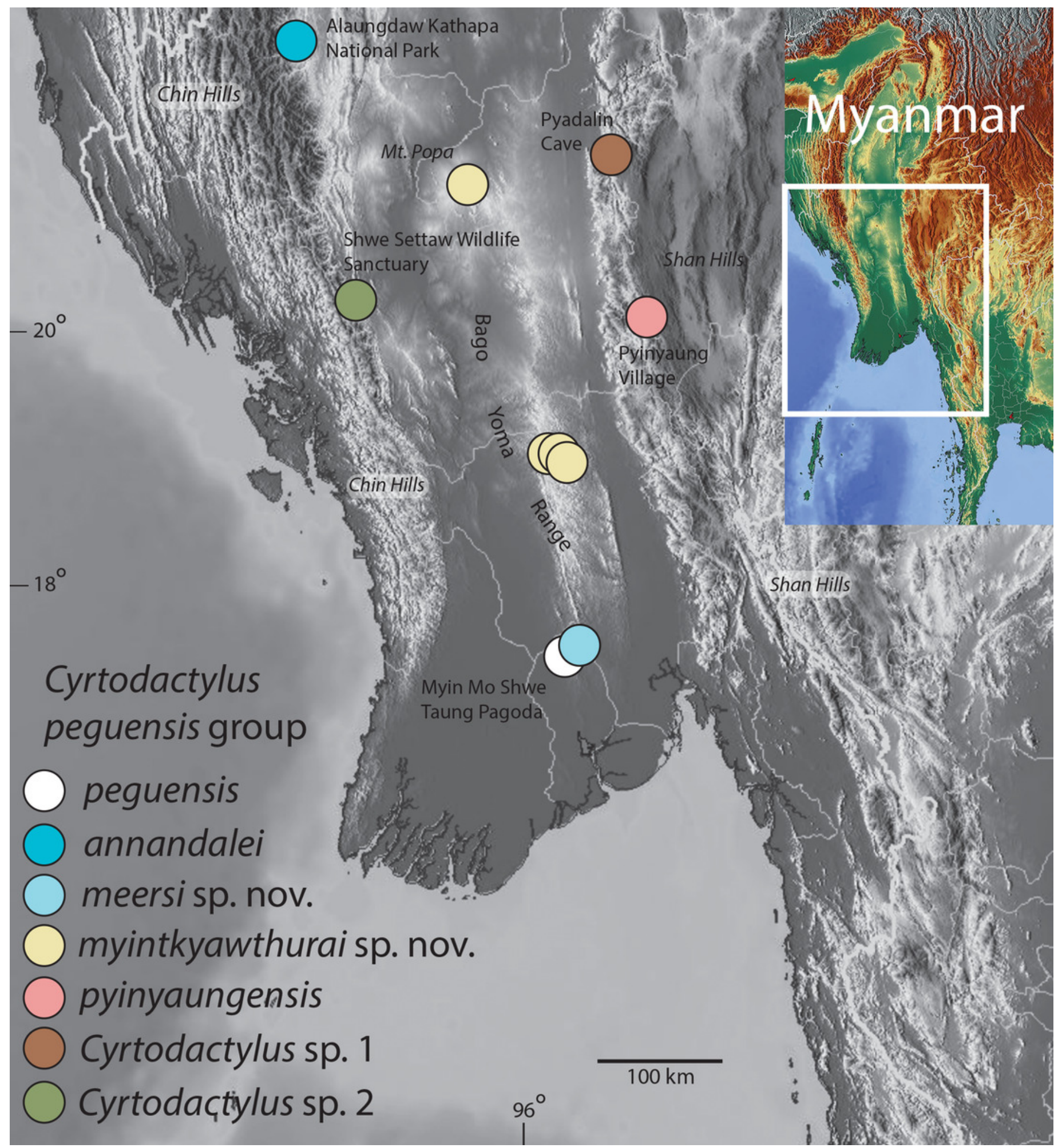




\section{Figure 2}

Phylogenetic relationships of the species of the Cyrtodactylus peguensis and C. oldhami groups.

Maximum likelihood consensus tree topology of Cyrtodactylus highlighting the distant phylogenetic position of the peguensis and oldhami groups. Black dots denote nodes with $\mathrm{BPP} \geq 0.95, \mathrm{LRT} \geq 0.80$, and UFB $\geq 95$. The grey dot connotes a node with $\mathrm{BPP} \geq 0.95, \mathrm{LRT} \leq$ 0.80 , and $\mathrm{UFB} \geq 95$. The white dot connotes a node with $\mathrm{BPP} \leq 0.95$, LRT $\leq 0.80$, and $\mathrm{UFB} \geq$ 95. Red arrow and red circle denote the node of the Indo-Burma clade (sensu Agarawal et al. 2014. Blue arrow and blue circle denote the node of the Indochinese clade (sensu Grismer 2017a). 


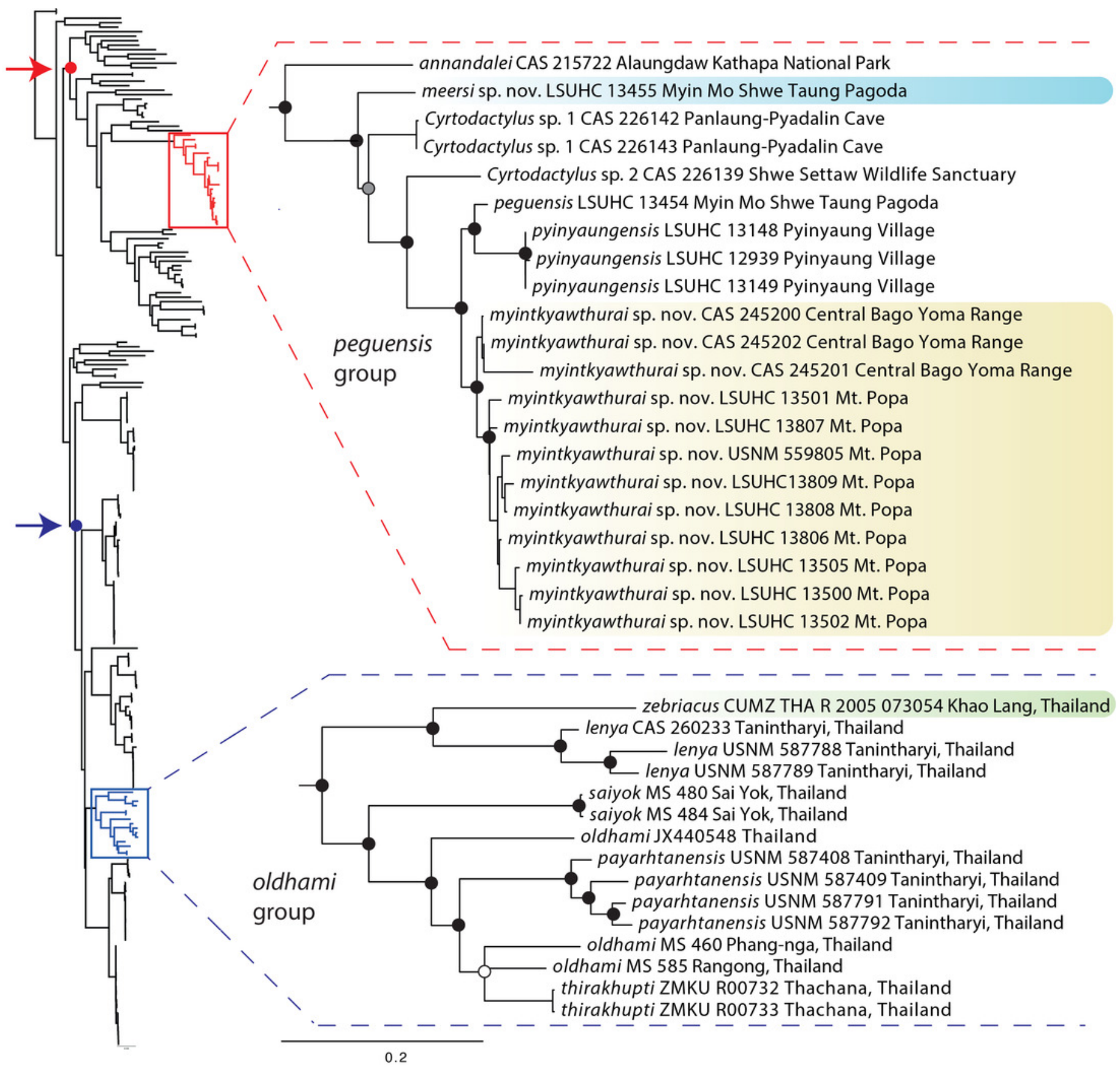


Figure 3

PCA and DAPC analyses of the Cyrtodactylus peguensis group.

PCA biplot (A) and DAPC (B) analyses showing the morphospatial relationships of the species of the peguensis group as well as the overlap of the reciprocally monophyletic populations of Cyrtodactylus myintkyawthurai sp. from Mt. Popa (MP) and the Bago Yoma (BY).
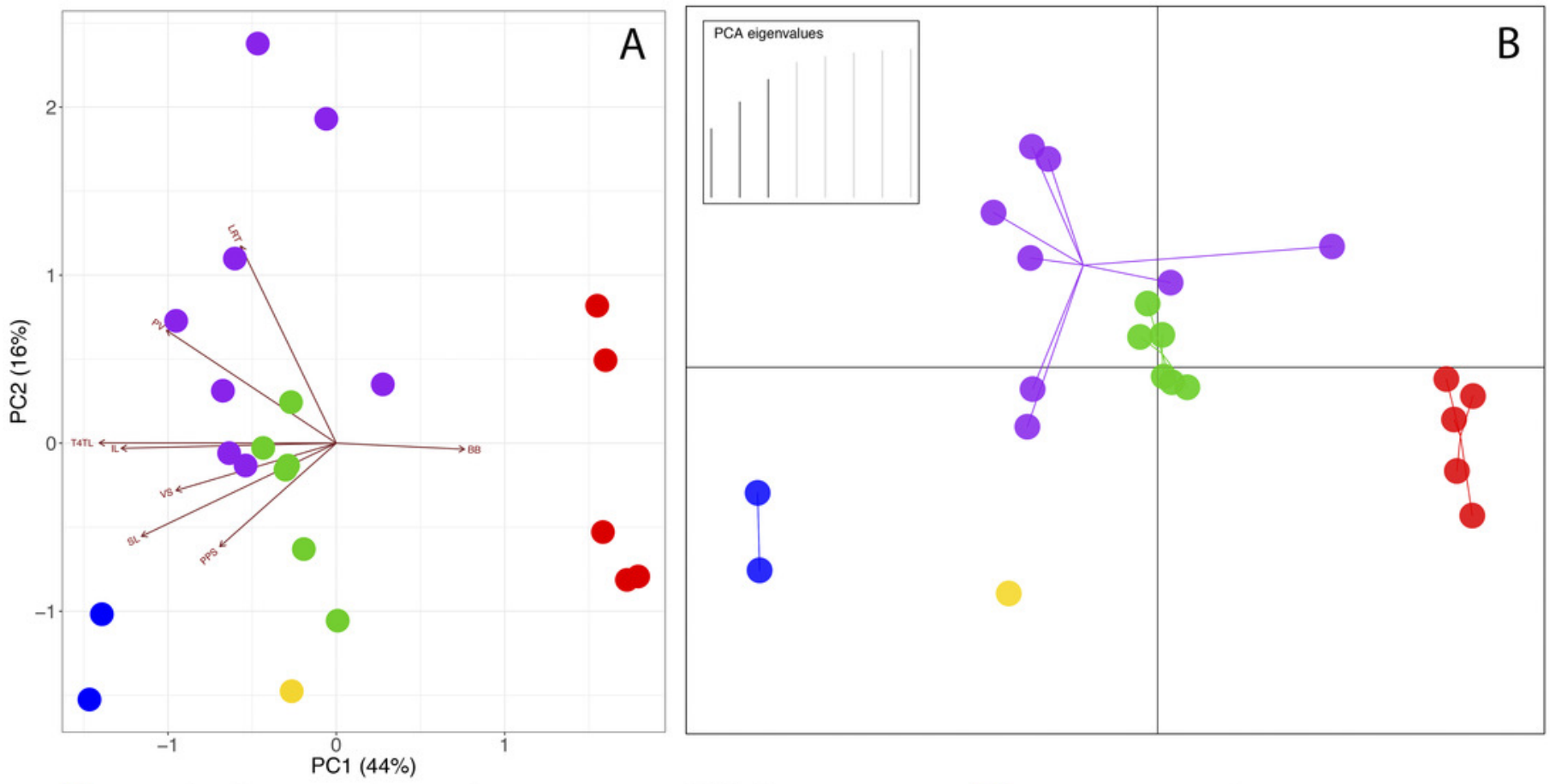

myintkyawthurai sp. nov. (BY) myintkyawthurai sp. nov. (MP) meersi sp. nov. 


\section{Figure 4}

Cyrtodactylus zebriacus and C. pyinyaungensis.

A. Uncollected specimen of Cyrtodactylus zebriacus (LSUDPC 10080) from Kanchandt, Surat Thani Province, Thailand. B. Cyrtodactylus pyinyaungensis (LSUHC 13150) from Pyinyaung Village, Mandalay Division, Myanmar.

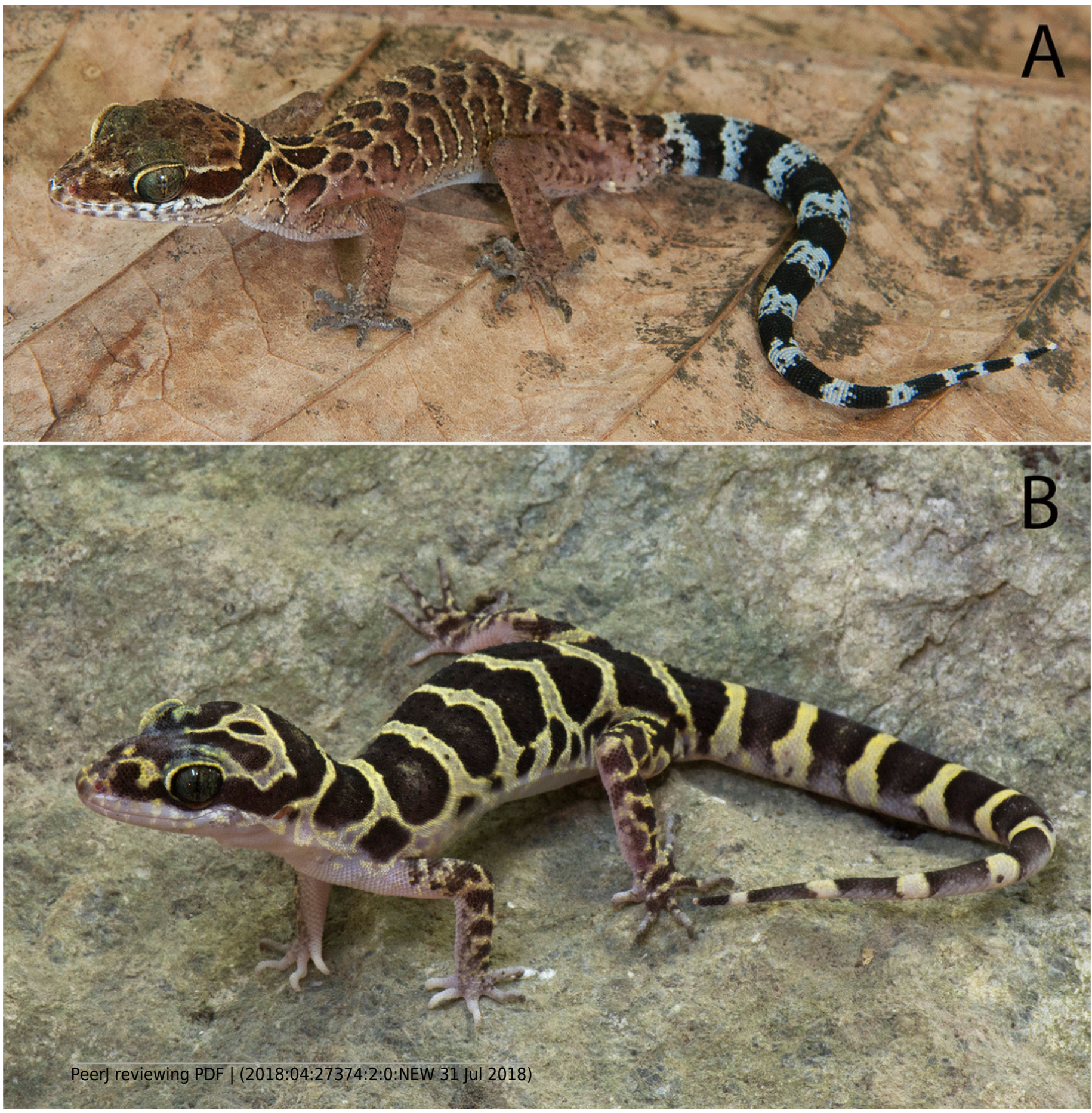




\section{Figure 5}

Type specimens and additional specimen of Cyrtodactylus peguensis.

Cyrtodactylus peguensis. A. Boulenger's (1893) illustration of the lost syntype from the type locality of Hpa Lon, Bago Division, Myanmar. B. Syntype BM 1946.3.23 from the type locality.

C. LSUHC 13454 from the Myin Mo Shwe Taung Pagoda, $9.5 \mathrm{~km}$ east of Hpa Lon, Bago Division, Myanmar.

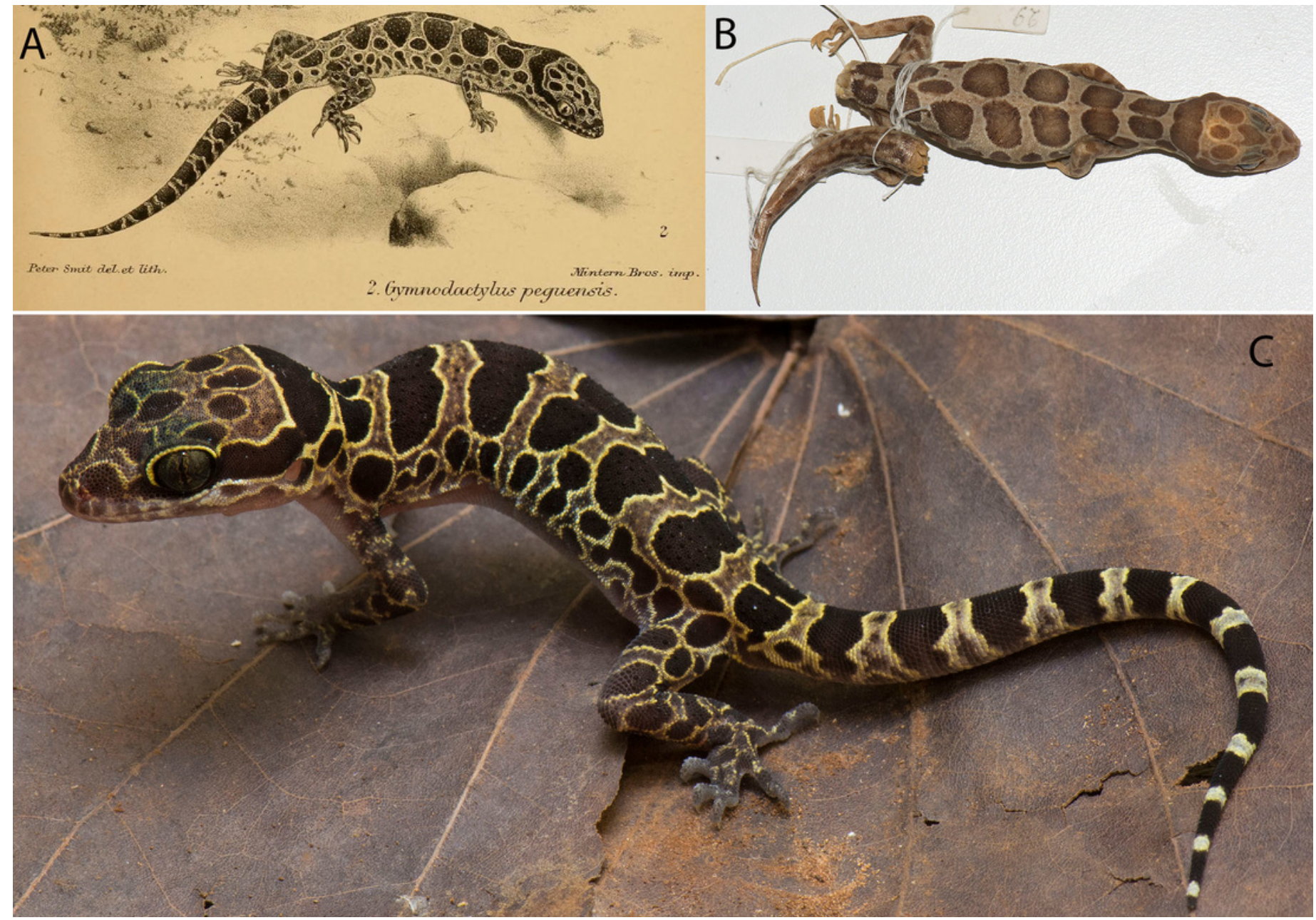




\section{Figure 6}

Type locality of Cyrtodactylus peguensis.

Habitat of Cyrtodactylus peguensis on the road just below the Myin Mo Shwe Taung Pagoda, Bago Division, Myanmar.

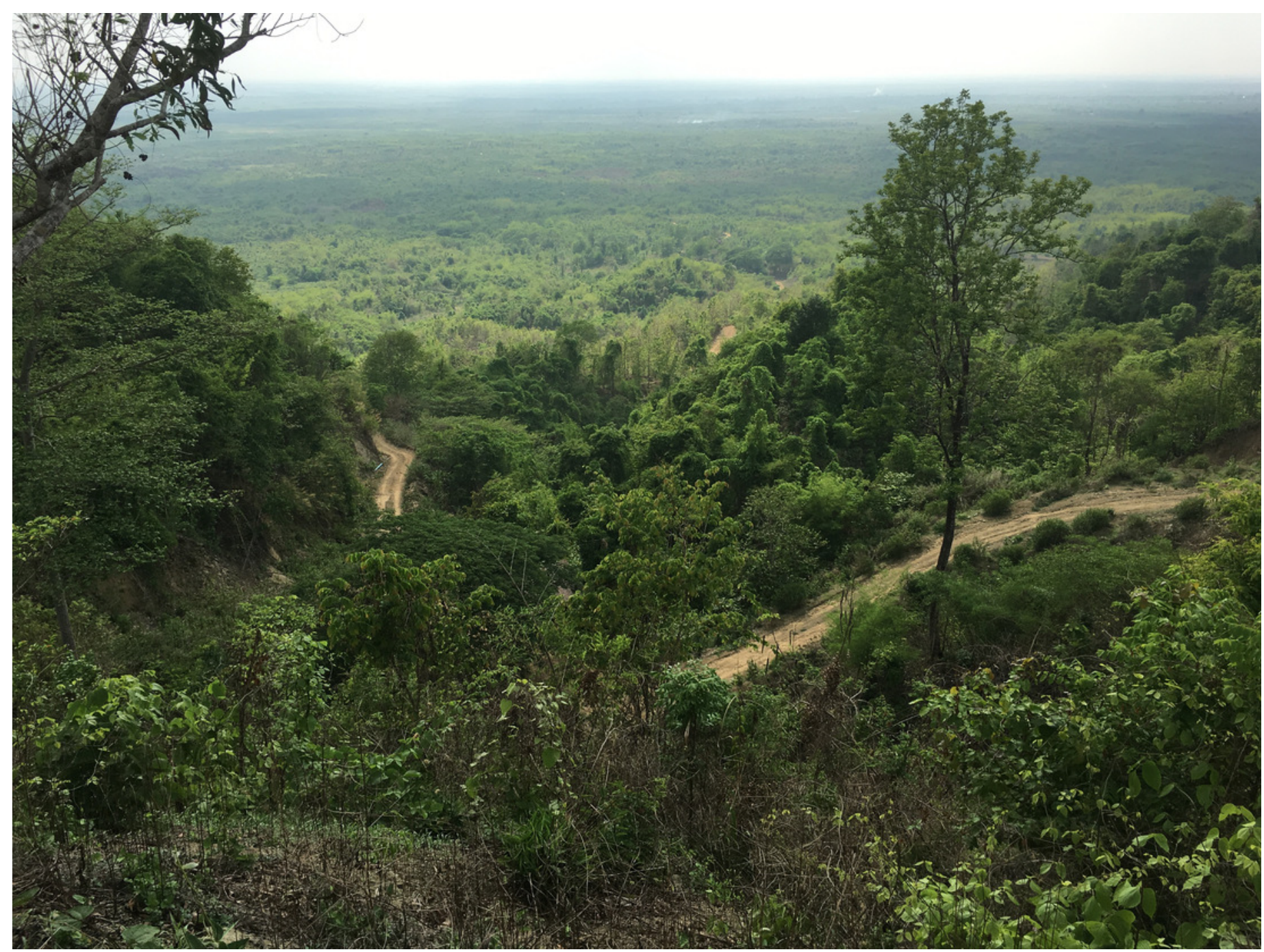




\section{Figure 7}

Holotype of Cyrtodactylus meersi.

Holotype of Cyrtodactylus meersi sp. nov. from the type locality of the Myin Mo Shwe Taung Pagoda, Bago Division, Myanmar.

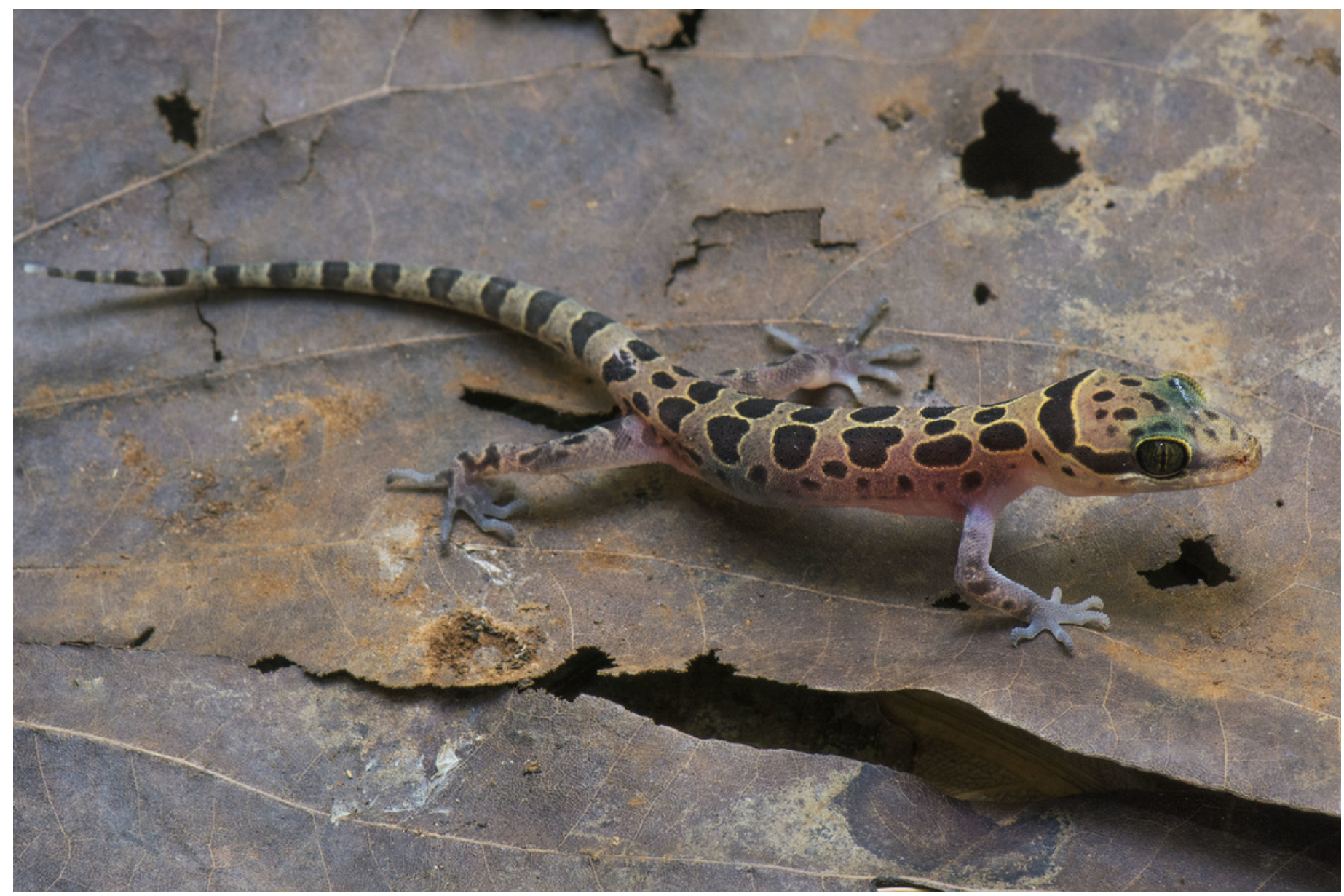




\section{Figure 8}

Type specimens of Cyrtodactylus myintkyawthurai sp. nov.

Cyrtodactylus myintkyawthurai sp. nov. from the type locality of Taung Twin Chaung camp, Mt. Popa, Kyauk-pa-taung Township, Mandalay Division, Myanmar. A. Adult male holotype LSUHC 13808. B. Adult male paratype LSUHC 13807. C. Subadult male paratype 13806. D. Juvenile male paratype LSUHC 13809.

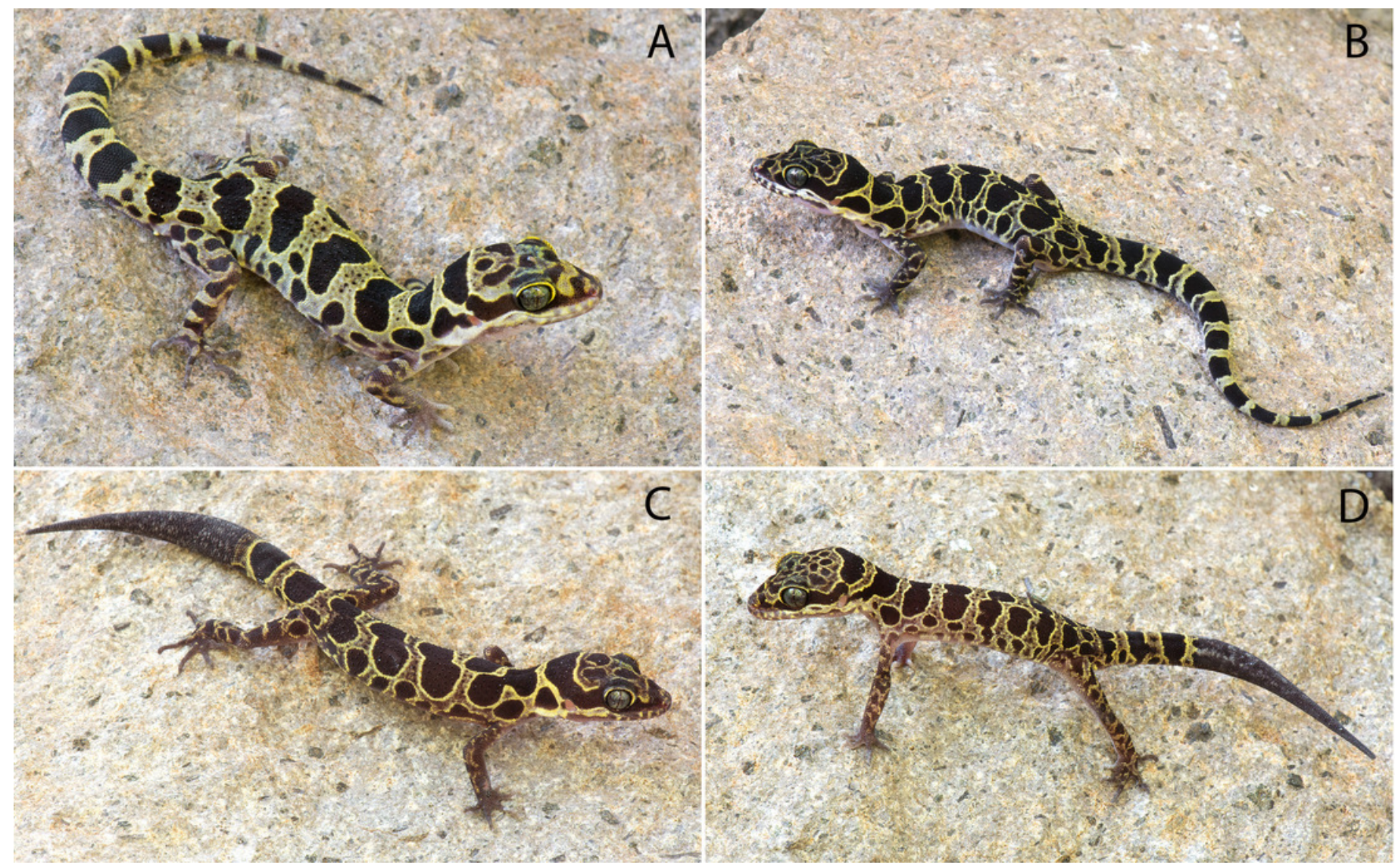




\section{Figure 9}

Habitat of Cyrtodactylus myintkyawthurai sp. nov.

Mixed dry dipterocarp forest habitat of Cyrtodactylus myintkyawthurai sp. nov. near the type locality of Taung Twin Chaung camp, Mt. Popa, Kyauk-pa-taung Township, Mandalay Division, Myanmar.

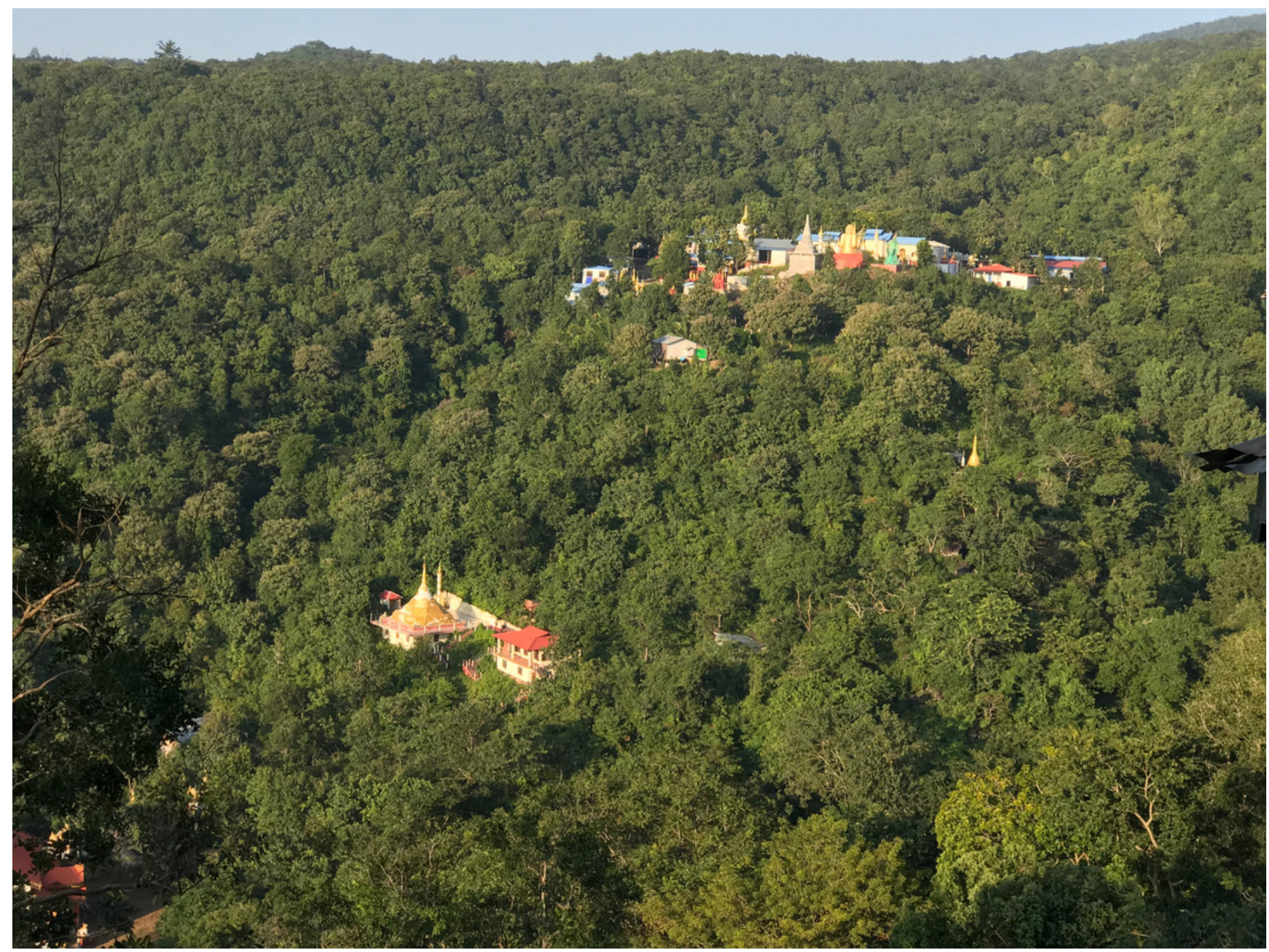




\section{Table $\mathbf{1}$ (on next page)}

Locality data and GenBank numbers of specimens used in this analysis.

GenBank accession numbers for the newly recorded specimens of the peguensis group used for the molecular phylogenetic analyses. Accession numbers for outgroups are in Agarwal et al. (2014) and for the other specimens of Cyrtodactylus of the Indochina clade see Grismer et al. $(2017 a, 2018)$. 
Table 1. GenBank accession numbers for the newly recorded specimens of the peguensis group used for the molecular phylogenetic analyses. Accession numbers for outgroups are in Agarwal et al. (2014) and for the other specimens of Cyrtodactylus of the Indochina clade see Grismer et al. (2017a, 2018).

\begin{tabular}{|c|c|c|c|}
\hline Taxon & $\begin{array}{l}\text { Catalog } \\
\text { no. }\end{array}$ & Locality & $\begin{array}{l}\text { GenBank } \\
\text { no. }\end{array}$ \\
\hline \multirow{5}{*}{$\begin{array}{l}\text { Cyrtodactylus meersi sp. nov. } \\
\text { holotype } \\
\text { Cyrtodactylus myintkyawthurai sp. } \\
\text { nov. }\end{array}$} & & $\begin{array}{l}\text { Myin Mo Swhe Taung Pagoda, Bago Division, } \\
\text { Taikkyi Township, Yangon (north) District, }\end{array}$ & \multirow{3}{*}{ MH624104 } \\
\hline & LSUHC & Myanmar $\left(17.46272^{\circ} \mathrm{N}, 96.01624^{\circ} \mathrm{E}\right.$, elevation & \\
\hline & 13455 & $162 \mathrm{~m})$ & \\
\hline & CAS & Central Bago Yoma, between Pallan Gyi Forest & \multirow[t]{2}{*}{ MH624107 } \\
\hline & 245200 & $\begin{array}{l}\text { Camp and summit, Bago Division, Myamnar } \\
\left(18.92108^{\circ} \mathrm{N}, 95.814027^{\circ} \mathrm{E}, 268 \mathrm{~m}\right) \text {. }\end{array}$ & \\
\hline \multirow{2}{*}{$\begin{array}{l}\text { Cyrtodactylus myintkyawthurai sp. } \\
\text { nov. }\end{array}$} & CAS & Central Bago Yoma, between Pallan Gyi Forest & \multirow[t]{2}{*}{ MH624117 } \\
\hline & 245201 & $\begin{array}{l}\text { Camp and summit, Bago Division, Myamnar } \\
\left(18.92108^{\circ} \mathrm{N}, 95.814027^{\circ} \mathrm{E}, 268 \mathrm{~m}\right) \text {. }\end{array}$ & \\
\hline \multirow{2}{*}{$\begin{array}{l}\text { Cyrtodactylus myintkyawthurai sp. } \\
\text { nov. }\end{array}$} & CAS & Central Bago Yoma, between Pallan Gyi Forest & \multirow[t]{2}{*}{ MH624108 } \\
\hline & 245202 & $\begin{array}{l}\text { Camp and summit, Bago Division, Myamnar } \\
\left(18.92108^{\circ} \mathrm{N}, 95.814027^{\circ} \mathrm{E}, 268 \mathrm{~m}\right) \text {. }\end{array}$ & \\
\hline \multirow{3}{*}{$\begin{array}{l}\text { Cyrtodactylus myintkyawthurai sp. } \\
\text { nov. }\end{array}$} & LSUHC & Taung Twin Chaung camp, Mt. Popa, Kyauk- & \multirow[t]{2}{*}{ MH624109 } \\
\hline & 13500 & $\begin{array}{l}\text { pa-taung Township, Mandalay Region, } \\
\text { Myanmar }\left(20.93087^{\circ} \mathrm{N}, 95.22580^{\circ} \mathrm{E} ; 978 \mathrm{~m} \text { in }\right. \\
\text { elevation). }\end{array}$ & \\
\hline & & $\begin{array}{l}\text { Taung Twin Chaung camp, Mt. Popa, Kyauk- } \\
\text { pa-taung Township, Mandalay Region, }\end{array}$ & \multirow[t]{2}{*}{ MH624116 } \\
\hline \multirow[t]{2}{*}{$\begin{array}{l}\text { Cyrtodactylus myintkyawthurai sp. } \\
\text { nov. }\end{array}$} & $\begin{array}{l}\text { LSUHC } \\
13501\end{array}$ & $\begin{array}{l}\text { Myanmar }\left(20.93087^{\circ} \mathrm{N}, 95.22580^{\circ} \mathrm{E} ; 978 \mathrm{~m} \text { in }\right. \\
\text { elevation). }\end{array}$ & \\
\hline & LSUHC & Taung Twin Chaung camp, Mt. Popa, Kyauk- & MH624110 \\
\hline \multirow[t]{3}{*}{$\begin{array}{l}\text { Cyrtodactylus myintkyawthurai sp. } \\
\text { nov. }\end{array}$} & 13502 & $\begin{array}{l}\text { pa-taung Township, Mandalay Region, } \\
\text { Myanmar }\left(20.93087^{\circ} \mathrm{N}, 95.22580^{\circ} \mathrm{E} ; 978 \mathrm{~m} \text { in }\right. \\
\text { elevation). }\end{array}$ & \\
\hline & LSUHC & Taung Twin Chaung camp, Mt. Popa, Kyauk- & MH624112 \\
\hline & 13505 & pa-taung Township, Mandalay Region, & \\
\hline \multirow[t]{2}{*}{$\begin{array}{l}\text { Cyrtodactylus myintkyawthurai sp. } \\
\text { nov. }\end{array}$} & & $\begin{array}{l}\text { Myanmar }\left(20.93087^{\circ} \mathrm{N}, 95.22580^{\circ} \mathrm{E} ; 978 \mathrm{~m} \text { in }\right. \\
\text { elevation). }\end{array}$ & \\
\hline & USNM & Popa Mountain Park, Mandalay Division, & JX440536 \\
\hline \multirow{3}{*}{$\begin{array}{l}\text { Cyrtodactylus myintkyawthurai sp. } \\
\text { nov. }\end{array}$} & 559805 & Myanmar & \\
\hline & LSUHC & Taung Twin Chaung camp, Mt. Popa, Kyauk- & MH624114 \\
\hline & 13806 & pa-taung Township, Mandalay Region, & \\
\hline \multirow[t]{3}{*}{$\begin{array}{l}\text { Cyrtodactylus myintkyawthurai sp. } \\
\text { nov. }\end{array}$} & & $\begin{array}{l}\text { Myanmar }\left(20.93087^{\circ} \mathrm{N}, 95.22580^{\circ} \mathrm{E} ; 978 \mathrm{~m} \text { in }\right. \\
\text { elevation). }\end{array}$ & \\
\hline & LSUHC & Taung Twin Chaung camp, Mt. Popa, Kyauk- & MH624115 \\
\hline & 13807 & pa-taung Township, Mandalay Region, & \\
\hline \multirow[t]{3}{*}{$\begin{array}{l}\text { Cyrtodactylus myintkyawthurai sp. } \\
\text { nov. holotype }\end{array}$} & & $\begin{array}{l}\text { Myanmar }\left(20.93087^{\circ} \mathrm{N}, 95.22580^{\circ} \mathrm{E} ; 978 \mathrm{~m} \text { in }\right. \\
\text { elevation). }\end{array}$ & \\
\hline & LSUHC & Taung Twin Chaung camp, Mt. Popa, Kyauk- & MH624113 \\
\hline & 13808 & pa-taung Township, Mandalay Region, & \\
\hline \multirow[t]{3}{*}{$\begin{array}{l}\text { Cyrtodactylus myintkyawthurai sp. } \\
\text { nov. }\end{array}$} & & $\begin{array}{l}\text { Myanmar }\left(20.93087^{\circ} \mathrm{N}, 95.22580^{\circ} \mathrm{E} ; 978 \mathrm{~m} \text { in }\right. \\
\text { elevation). }\end{array}$ & \\
\hline & LSUHC & Taung Twin Chaung camp, Mt. Popa, Kyauk- & MH624111 \\
\hline & 13809 & pa-taung Township, Mandalay Region, & \\
\hline \multirow[t]{3}{*}{$\begin{array}{l}\text { Cyrtodactylus myintkyawthurai sp. } \\
\text { nov. }\end{array}$} & & $\begin{array}{l}\text { Myanmar }\left(20.93087^{\circ} \mathrm{N}, 95.22580^{\circ} \mathrm{E} ; 978 \mathrm{~m} \text { in }\right. \\
\text { elevation). }\end{array}$ & \\
\hline & LSUHC & $5.3 \mathrm{~km}$ north of Pyinyaung Village at the & MH624119 \\
\hline & 13139 & Apache Cement factory mining site, Mandalay & \\
\hline Cyrtodactylus pyinyaungensis & & Region, Myanmar (N2052.191, E96²4.296; & \\
\hline
\end{tabular}




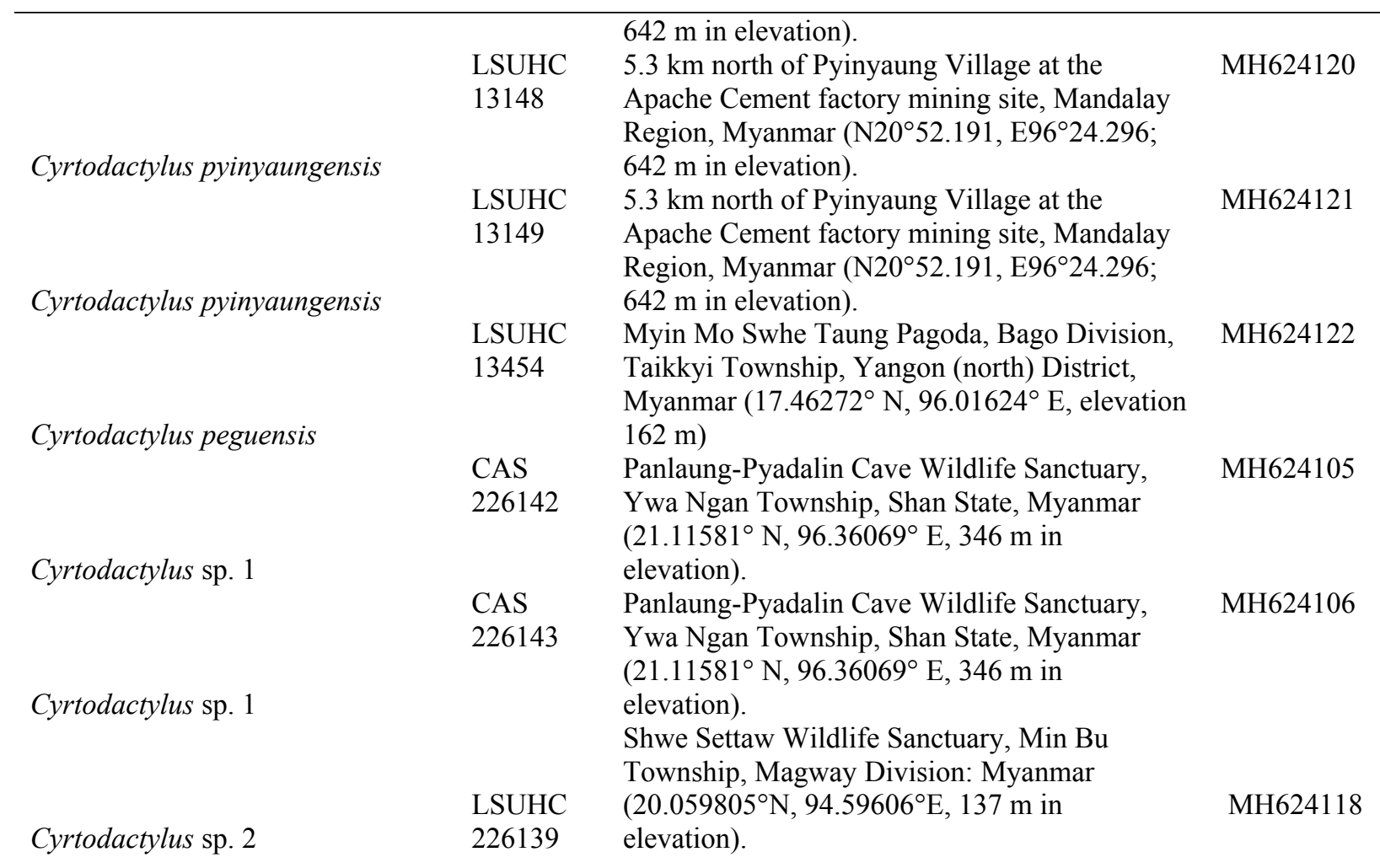




\section{Table 2 (on next page)}

Primer sequences used in this study for amplification and sequencing the ND2 gene and the flanking tRNAs. 
Table 2. Primer sequences used in this study for amplification and sequencing the ND2 gene and the flanking tRNAs.

\begin{tabular}{llll} 
Primer name & Primer reference & \multicolumn{2}{c}{ Sequence } \\
\hline L4437b & (Macey et al., 1997) & External & 5'-AAGCAGTTGGGCCCATACC-3' \\
H5934 & (Macey et al., 1997) & External & 5' -AGRGTGCCAATGTCTTTGTGRTT-3' \\
\hline
\end{tabular}
1 


\section{Table 3 (on next page)}

Percent uncorrected pair-wise sequence divergence among individuals and species of the Cyrtodactylus peguensis group and C. zebriacus calculated from 1467 base pairs of the mitochondrial gene ND2. 


\begin{tabular}{|c|c|c|c|c|c|c|c|c|c|c|c|c|c|c|c|c|c|c|c|c|c|c|}
\hline 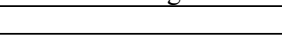 & 1 & 2 & 3 & 4 & 5 & 6 & 7 & 8 & 9 & 10 & 11 & 12 & 13 & 14 & 15 & 16 & 17 & 18 & 19 & 20 & 21 & 22 \\
\hline $\begin{array}{l}\text { 1. zebriacus CUMZ } 2005 \\
073054\end{array}$ & $* * *$ & $* * *$ & $* * *$ & $* * *$ & $* * *$ & $* * *$ & $* * *$ & $* * *$ & $* * *$ & $* * *$ & $* * *$ & $* * *$ & $* * *$ & $* * *$ & $* * *$ & $* * *$ & $* * *$ & $* * *$ & $* * *$ & $* * *$ & $* * *$ & $* * *$ \\
\hline $\begin{array}{l}\text { 2. Cyrtodactylus sp.1 CAS } \\
\text { 226139 }\end{array}$ & 0.303 & $* * *$ & $* * *$ & $* * *$ & $* * *$ & $* * *$ & $* * *$ & $* * *$ & $* * *$ & $* * *$ & $* * *$ & $* * *$ & $* * *$ & $* * *$ & $* * *$ & $* * *$ & $* * *$ & $* * *$ & $* * *$ & $* * *$ & $* * *$ & $* * *$ \\
\hline $\begin{array}{l}\text { 3. Cyrtodactylus sp.2 CAS } \\
226142\end{array}$ & 0.283 & 0.097 & $* * *$ & $* * *$ & $* * *$ & $* * *$ & $* * *$ & $* * *$ & $* * *$ & $* * *$ & $* * *$ & $* * *$ & $* * *$ & $* * *$ & $* * *$ & $* * *$ & $* * *$ & $* * *$ & $* * *$ & $* * *$ & $* * *$ & $* * *$ \\
\hline $\begin{array}{l}\text { 4. Cyrtodactylus sp.2 CAS } \\
226143\end{array}$ & 0.280 & 0.093 & 0.003 & $* * *$ & $* * *$ & $* * *$ & $* * *$ & $* * *$ & $* * *$ & $* * *$ & $* * *$ & $* * *$ & $* * *$ & $* * *$ & $* * *$ & $* * *$ & $* * *$ & $* * *$ & $* * *$ & $* * *$ & $* * *$ & $* * *$ \\
\hline $\begin{array}{l}\text { 5. meersi sp. nov. LSUHC } \\
13455\end{array}$ & 0.283 & 0.100 & 0.110 & 0.107 & $* * *$ & $* * *$ & $* * *$ & $* * *$ & $* * *$ & $* * *$ & $* * *$ & $* * *$ & $* * *$ & $* * *$ & $* * *$ & $* * *$ & $* * *$ & $* * *$ & $* * *$ & $* * *$ & $* * *$ & $* * *$ \\
\hline $\begin{array}{l}\text { 6. myinttyawthurai sp. nov. } \\
\text { Bago Yoma CAS } 245200\end{array}$ & 0.293 & 0.117 & 0.097 & 0.093 & 0.113 & $* * *$ & $* * *$ & $* * *$ & $* * *$ & $* * *$ & $* * *$ & $* * *$ & $* * *$ & $* * *$ & $* * *$ & $* * *$ & $* * *$ & $* * *$ & $* * *$ & $* * *$ & $* * *$ & $* * *$ \\
\hline $\begin{array}{l}\text { 7. myinttyawthurai sp. nov. } \\
\text { Bago Yoma CAS } 245202\end{array}$ & 0.293 & 0.113 & 0.093 & 0.090 & 0.110 & 0.003 & $* * *$ & $* * *$ & $* * *$ & $* * *$ & $* * *$ & $* * *$ & $* * *$ & $* * *$ & $* * *$ & $* * *$ & $* * *$ & $* * *$ & $* * *$ & $* * *$ & $* * *$ & $* * *$ \\
\hline $\begin{array}{l}\text { 8. myinttyawthurai sp. nov. } \\
\text { Bago Yoma CAS } 245201\end{array}$ & 0.303 & 0.123 & 0.103 & 0.100 & 0.117 & 0.013 & 0.010 & $* * *$ & $* * *$ & $* * *$ & $* * *$ & $* * *$ & $* * *$ & $* * *$ & $* * *$ & $* * *$ & $* * *$ & $* * *$ & $* * *$ & $* * *$ & $* * *$ & $* * *$ \\
\hline $\begin{array}{l}\text { 9. myinttyawthurai sp. nov. } \\
\text { Mt. Popa LSUHC } 13500\end{array}$ & 0.313 & 0.117 & 0.103 & 0.100 & 0.120 & 0.033 & 0.030 & 0.040 & $* * *$ & $* * *$ & $* * *$ & $* * *$ & $* * *$ & $* * *$ & $* * *$ & $* * *$ & $* * *$ & $* * *$ & $* * *$ & $* * *$ & $* * *$ & $* * *$ \\
\hline $\begin{array}{l}\text { 10. myintkyawthurai sp. nov. } \\
\text { Mt. Popa LSUHC } 13502\end{array}$ & 0.313 & 0.117 & 0.103 & 0.100 & 0.120 & 0.033 & 0.030 & 0.040 & 0.000 & $* * *$ & $* * *$ & $* * *$ & $* * *$ & $* * *$ & $* * *$ & $* * *$ & $* * *$ & $* * *$ & $* * *$ & $* * *$ & $* * *$ & $* * *$ \\
\hline $\begin{array}{l}\text { 11. myintkyawthurai sp. nov. } \\
\text { Mt. Popa LSUHC } 13809\end{array}$ & 0.313 & 0.117 & 0.103 & 0.100 & 0.120 & 0.033 & 0.030 & 0.040 & 0.000 & 0.000 & $* * *$ & $* * *$ & $* * *$ & $* * *$ & $* * *$ & $* * *$ & $* * *$ & $* * *$ & $* * *$ & $* * *$ & $* * *$ & $* * *$ \\
\hline $\begin{array}{l}\text { 12. myintkyawthurai sp. nov. } \\
\text { Mt. Popa LSUHC } 13806\end{array}$ & 0.313 & 0.117 & 0.103 & 0.100 & 0.120 & 0.033 & 0.030 & 0.040 & 0.000 & 0.000 & 0.000 & $* * *$ & $* * *$ & $* * *$ & $* * *$ & $* * *$ & $* * *$ & $* * *$ & $* * *$ & $* * *$ & $* * *$ & $* * *$ \\
\hline $\begin{array}{l}\text { 13. myintkyawthurai sp. nov. } \\
\text { Mt. Popa LSUHC } 13808\end{array}$ & 0.313 & 0.117 & 0.103 & 0.100 & 0.120 & 0.033 & 0.030 & 0.040 & 0.000 & 0.000 & 0.000 & 0.000 & $* * *$ & $* * *$ & $* * *$ & $* * *$ & $* * *$ & $* * *$ & $* * *$ & $* * *$ & $* * *$ & $* * *$ \\
\hline $\begin{array}{l}\text { 14. myintkyawthurai } \text { sp. nov. } \\
\text { Mt. Popa LSUHC } 13807\end{array}$ & 0.313 & 0.117 & 0.103 & 0.100 & 0.120 & 0.033 & 0.030 & 0.040 & 0.000 & 0.000 & 0.000 & 0.000 & 0.000 & $* * *$ & $* * *$ & $* * *$ & $* * *$ & $* * *$ & $* * *$ & $* * *$ & $* * *$ & $* * *$ \\
\hline $\begin{array}{l}\text { 15. myintkyawthurai sp. nov. } \\
\text { Mt. Popa LSUHC } 13505\end{array}$ & 0.313 & 0.117 & 0.103 & 0.100 & 0.120 & 0.033 & 0.030 & 0.040 & 0.000 & 0.000 & 0.000 & 0.000 & 0.000 & 0.000 & $* * *$ & $* * *$ & $* * *$ & $* * *$ & $* * *$ & $* * *$ & $* * *$ & $* * *$ \\
\hline $\begin{array}{l}\text { 16. myintkyawthurai } \text { sp. nov. } \\
\text { Mt. Popa LSUHC } 13501\end{array}$ & 0.313 & 0.117 & 0.103 & 0.100 & 0.120 & 0.033 & 0.030 & 0.040 & 0.000 & 0.000 & 0.000 & 0.000 & 0.000 & 0.000 & 0.000 & $* * *$ & $* * *$ & $* * *$ & $* * *$ & $* * *$ & $* * *$ & $* * *$ \\
\hline $\begin{array}{l}\text { 17. myintkyawthurai } \text { sp. nov. } \\
\text { Mt. Popa USNM } 559805\end{array}$ & 3 & 0. & 0. & 0. & 0. & 33 & 0.030 & 0.040 & 0.000 & 0.000 & 0.000 & 0.000 & 0.000 & 0.000 & 0.000 & 0.000 & $* * *$ & $* * *$ & $* * *$ & $* * *$ & $* * *$ & $* * *$ \\
\hline 18. peguensis LSUHC 13454 & 0.293 & 0.093 & 0.093 & 0.090 & 0.103 & 0.043 & 0.040 & 0.050 & 0.050 & 0.050 & 0.050 & 0.050 & 0.050 & 0.050 & 0.050 & 0.050 & 0.050 & $* * *$ & $* * *$ & $* * *$ & $* * *$ & $* * *$ \\
\hline $\begin{array}{l}\text { 19. pyinyaungensis LSUHC } \\
\text { 12939 }\end{array}$ & 0.293 & 0.100 & 0.093 & 0.090 & 0.117 & 0.047 & 0.043 & 0.053 & 0.050 & 0.050 & 0.050 & 0.050 & 0.050 & 0.050 & 0.050 & 0.050 & 0.050 & 0.033 & $* * *$ & $* * *$ & $* * *$ & $* * *$ \\
\hline $\begin{array}{l}\text { 20. pyinyaungensis LSUHC } \\
\text { 13149 }\end{array}$ & 0.293 & 0.100 & 0.093 & 0.090 & 0.117 & 0.047 & 0.043 & 0.053 & 0.050 & 0.050 & 0.050 & 0.050 & 0.050 & 0.050 & 0.050 & 0.050 & 0.050 & 0.033 & 0.000 & **** & $* * *$ & $* * *$ \\
\hline $\begin{array}{l}\text { 21. pyinyaungensis LSUHC } \\
13148\end{array}$ & 0.293 & 0.100 & 0.093 & 0.090 & 0.117 & 0.047 & 0.043 & 0.053 & 0.050 & 0.050 & 0.050 & 0.050 & 0.050 & 0.050 & 0.050 & 0.050 & 0.050 & 0.033 & 0.000 & 0.000 & $* * *$ & $* * *$ \\
\hline 22. annandalei CAS 215722 & 0.280 & 0.103 & 0.143 & 0.140 & 0.137 & 0.153 & 0.150 & 0.160 & 0.153 & 0.153 & 0.153 & 0.153 & 0.153 & 0.153 & 0.153 & 0.153 & 0.153 & 0.150 & 0.143 & 0.143 & 0.143 & $* * *$ \\
\hline
\end{tabular}




\section{Table 4 (on next page)}

Meristic, mensural, and color pattern data for Cyrtodactylus peguensis and C. meersi sp. nov. 


\begin{tabular}{|c|c|c|c|}
\hline & $\mathrm{BM}$ & LSUHC & LSUHC \\
\hline & 19468.23 .10 & 13454 & 13455 \\
\hline & syntype & & holotype \\
\hline & peguensis & peguensis & meersi sp. nov. \\
\hline $\operatorname{sex}$ & $\mathrm{m}$ & $\mathrm{m}$ & juvenile \\
\hline supralabials & 7 & 7 & 7 \\
\hline infralabials & 7 & 7 & 8 \\
\hline body tubercles low and rounded (dome-shaped) & yes & yes & yes \\
\hline body tubercles pointed and strongly keeked (triangular) & no & no & no \\
\hline no. of paravertebral tubercles & 32 & 31 & 32 \\
\hline no. longitudinal rows of tubercles & 17 & 19 & 13 \\
\hline tubercles on at least anterior $1 / 3$ of tail & 1 & no & no \\
\hline no. of ventral scales & 37 & 36 & 32 \\
\hline subdigital lamellae on 4 th toe & 19 & 19 & 17 \\
\hline total number of femoral pores in males & 19 & 17 & 12 \\
\hline number of precloacal pores in males & 8 & 8 & 8 \\
\hline post-precloacal scales rows & 3 & 3 & 2 \\
\hline transeverse subcaudal 2-3 times wider than long & l & yes & yes \\
\hline dorsal pattern with paravertebrtal elements & yes & variable & yes \\
\hline paravertebral elements not in contact & yes & variable & yes \\
\hline number of body bands & 5 & 5 & 5 \\
\hline number of light bands on tail & 1 & 12 & 11 \\
\hline number of dark bands on tail & 1 & 13 & 10 \\
\hline SVL & 70 & 44 & 36 \\
\hline $\mathrm{TL}$ & 5.9 & 46 & 38 \\
\hline TW & 6.6 & & \\
\hline FL & 10 & & \\
\hline TBL & 12.3 & & \\
\hline $\mathrm{AG}$ & 30 & & \\
\hline HL & 20.2 & & \\
\hline HW & 11.5 & & \\
\hline HD & 8.9 & & \\
\hline ED & 4.2 & & \\
\hline $\mathrm{EE}$ & 5.7 & & \\
\hline ES & 7.7 & & \\
\hline EN & 6.2 & & \\
\hline $\mathrm{IO}$ & 5.1 & & \\
\hline
\end{tabular}




\section{Table 5 (on next page)}

Summary statistics and principal component analysis scores for the species of the peguensis group.

Abbreviations are listed in the Materials and methods. 


\begin{tabular}{|c|c|c|c|c|c|c|c|c|}
\hline Standard deviation & 1.87977 & 1.14550 & 1.04649 & 0.88399 & 0.76149 & 0.58707 & 0.45129 & 0.38658 \\
\hline $\begin{array}{l}\text { Proportion of } \\
\text { Variance }\end{array}$ & 0.44171 & 0.16402 & 0.13689 & 0.09768 & 0.07248 & 0.04308 & 0.02546 & 0.01868 \\
\hline $\begin{array}{l}\text { Cumulative } \\
\text { Proportion }\end{array}$ & 0.44171 & 0.60572 & 0.74261 & 0.84029 & 0.91278 & 0.95586 & 0.98132 & 1.00000 \\
\hline Eigenvalue & 3.53357 & 1.31218 & 1.09514 & 0.78144 & 0.57987 & 0.34466 & 0.20366 & 0.14944 \\
\hline SL & -0.41562 & -0.11994 & 0.43799 & -0.04827 & 0.26991 & -0.29239 & 0.58088 & 0.35060 \\
\hline IL & -0.45874 & 0.08613 & 0.18604 & 0.25940 & 0.15835 & -0.26483 & -0.74375 & 0.17843 \\
\hline PVT & -0.34827 & 0.40331 & -0.21661 & 0.45143 & 0.04823 & 0.61796 & 0.20295 & 0.19983 \\
\hline LRT & -0.20080 & 0.34158 & -0.71353 & -0.29496 & 0.03732 & -0.45765 & 0.09269 & 0.16560 \\
\hline $\mathrm{VS}$ & -0.24605 & -0.56588 & -0.26397 & -0.43539 & 0.33955 & 0.43168 & -0.17252 & 0.16900 \\
\hline $4 \mathrm{TL}$ & -0.49952 & -0.03722 & -0.03150 & -0.00330 & 0.07709 & -0.03537 & 0.11926 & -0.85244 \\
\hline PPS & -0.24112 & -0.53611 & -0.23620 & 0.34100 & -0.66325 & -0.13589 & 0.08476 & 0.12963 \\
\hline BB & 0.29492 & -0.29969 & -0.30170 & 0.57768 & 0.58068 & -0.21672 & 0.09186 & -0.07646 \\
\hline
\end{tabular}




\section{Table 6(on next page)}

Meristic, mensural, and color pattern data for Cyrtodactylus myintkywathurai sp. nov.

All measurements are in $\mathrm{mm} . \mathrm{r}=$ regenerated; / = data unobtainable. 


\begin{tabular}{|c|c|c|c|c|c|c|c|c|}
\hline & LSUHC & LSUHC & LSUHC & LSUHC & LSUHC & LSUHC & LSUHC & LSUHC \\
\hline & 13808 & 13502 & 13501 & 13500 & 13505 & 13807 & 13809 & 13806 \\
\hline & holotype & paratype & paratype & paratype & paratype & paratype & paratype & paratype \\
\hline & $\begin{array}{l}\text { myintkyawthurai } \\
\text { sp. nov. }\end{array}$ & $\begin{array}{c}\text { myintkyawthurai } \\
\text { sp. nov. }\end{array}$ & $\begin{array}{l}\text { myintkyawthurai } \\
\text { sp. nov. }\end{array}$ & $\begin{array}{l}\text { myintkyawthurai } \\
\text { sp. nov. }\end{array}$ & $\begin{array}{l}\text { myintkyawthurai } \\
\text { sp. nov. }\end{array}$ & $\begin{array}{l}\text { myintkyawthurai } \\
\text { sp. nov. }\end{array}$ & $\begin{array}{l}\text { myintkyawthurai } \\
\text { sp. nov. }\end{array}$ & $\begin{array}{l}\text { myintkyawthurai } \\
\text { sp. nov. }\end{array}$ \\
\hline & Mt. Popa & Mt. Popa & Mt. Popa & Mt. Popa & Mt. Popa & Mt. Popa & Mt. Popa & Mt. Popa \\
\hline sex & $\mathrm{m}$ & $\mathrm{f}$ & $\mathrm{m}$ & $\mathrm{m}$ & $\mathrm{f}$ & $\mathrm{m}$ & $\mathrm{f}$ & $\mathrm{m}$ \\
\hline supralabials & 6 & 6 & 6 & 7 & 7 & 7 & 7 & 7 \\
\hline infralabials & 6 & 7 & 7 & 7 & 7 & 7 & 7 & 7 \\
\hline $\begin{array}{l}\text { body tubercles low } \\
\text { and rounded (dome- } \\
\text { shaped) }\end{array}$ & no & no & no & no & no & no & no & no \\
\hline $\begin{array}{l}\text { body tubercles pointed } \\
\text { and keeked } \\
\text { (triangular) }\end{array}$ & yes & yea & yes & yes & yes & yes & yes & yes \\
\hline $\begin{array}{l}\text { no. of paravertebral } \\
\text { tubercles }\end{array}$ & 31 & 33 & 33 & 31 & 32 & 33 & 31 & 30 \\
\hline $\begin{array}{l}\text { no. longitudinal rows } \\
\text { of tubercles }\end{array}$ & 17 & 21 & 23 & 21 & 19 & 18 & 17 & 18 \\
\hline no. of ventral scales & 35 & 34 & 35 & 32 & 32 & 35 & 32 & 33 \\
\hline $\begin{array}{l}\text { subdigital lamellae on } \\
\text { 4th toe }\end{array}$ & 17 & 18 & 17 & 17 & 19 & 18 & 19 & 18 \\
\hline $\begin{array}{l}\text { enlarged femoral } \\
\text { scales and precloacal } \\
\text { scales continuous }\end{array}$ & 1 & 1 & 1 & 1 & 1 & 1 & 1 & 1 \\
\hline $\begin{array}{l}\text { total number of } \\
\text { femoral pores }\end{array}$ & 12 & dimples & 16 & 20 & 0 (juv) & 14 & 8 & 12 \\
\hline $\begin{array}{l}\text { number of precloacal } \\
\text { pores in males }\end{array}$ & 7 & 5 & 8 & 8 & $0($ juv $)$ & 7 & 8 & 8 \\
\hline $\begin{array}{l}\text { post-precloacal scales } \\
\text { rows }\end{array}$ & 2 & 2 & 2 & 2 & 2 & 2 & 2 & 2 \\
\hline $\begin{array}{l}\text { transeverse subcaudal } \\
2-3 \text { times wider than } \\
\text { long }\end{array}$ & no & 1 & no & no & no & no & no & no \\
\hline $\begin{array}{l}\text { dorsal pattern with } \\
\text { paravertebrtal } \\
\text { elements }\end{array}$ & yes & variable & no & yes & yes & yes & yes & yes \\
\hline $\begin{array}{l}\text { paravertebral elements } \\
\text { not in contact }\end{array}$ & no & no & no & no & no & no & no & no \\
\hline number of body bands & 4 & 6 & 5 & 4 & 4 & 6 & 5 & 4 \\
\hline $\begin{array}{l}\text { number of light bands } \\
\text { on tail }\end{array}$ & 11 & 1 & 1 & 1 & 9 & 12 & 1 & 1 \\
\hline $\begin{array}{l}\text { number of dark bands } \\
\text { on tail }\end{array}$ & 10 & 1 & 1 & 1 & 10 & 11 & 1 & 1 \\
\hline SVL & 57.6 & 75.1 & 63 & 58.8 & 41.7 & 57 & 53.3 & 51.2 \\
\hline TL & 64 & $\mathrm{r}$ & $\mathrm{r}$ & $\mathrm{r}$ & & 68 & $\mathrm{r}$ & $\mathrm{r}$ \\
\hline TW & 5.9 & 6.7 & 7.3 & 6.4 & 3.5 & 5 & 5.1 & 4.7 \\
\hline FL & 9 & 9.9 & 8.4 & 8.2 & 7 & 8.3 & 7.3 & 7.9 \\
\hline
\end{tabular}




\begin{tabular}{|c|c|c|c|c|c|c|c|c|}
\hline TBL & $\begin{array}{l}8.8 \\
\end{array}$ & 12.3 & 10.4 & 10.3 & 7.4 & 10.1 & 9 & 8.8 \\
\hline $\mathrm{AG}$ & 27.2 & 35.8 & 27.3 & 24.2 & 18.1 & 27.7 & 23.7 & 23.3 \\
\hline $\mathrm{HL}$ & 16.1 & 18.4 & 16.6 & 17.1 & 12.4 & 15.5 & 14.8 & 13.5 \\
\hline HW & 11.3 & 14.1 & 10.7 & 11.2 & 7.7 & 10.8 & 10.1 & 9.6 \\
\hline $\mathrm{HD}$ & 7 & 8.8 & 7.4 & 6.8 & 4.9 & 6.1 & 6.7 & 6.5 \\
\hline ED & 4.3 & 4.5 & 3.6 & 3.3 & 2.7 & 3.3 & 4.1 & 4 \\
\hline $\mathrm{EE}$ & 4.5 & 5.8 & 4.2 & 4.6 & 3.3 & 4.3 & 4 & 4 \\
\hline ES & 6.4 & 8.2 & 6.8 & 6.3 & 5 & 6.3 & 6.7 & 5.9 \\
\hline EN & 5.6 & 5.6 & 4.5 & 4.5 & 3.2 & 4.7 & 5.9 & 4.7 \\
\hline IO & 4.7 & 6.7 & 5.2 & $\begin{array}{l}4.7 \\
\end{array}$ & 3.6 & 5 & 4.8 & 3.9 \\
\hline EL & 2.1 & 2.1 & $\begin{array}{l}1.7 \\
\end{array}$ & 2.1 & 1.4 & 1.8 & 2.1 & 1.9 \\
\hline IN & 2.1 & 2.7 & 2.4 & 2.2 & 2 & 2.2 & 2.3 & 1.8 \\
\hline
\end{tabular}

\begin{tabular}{|c|c|c|c|c|c|c|}
\hline & CAS & CAS & CAS & CAS & CAS & CAS \\
\hline & 245200 & 245202 & 222147 & 245203 & 222128 & 245201 \\
\hline & paratype & paratype & paratype & paratype & paratype & paratype \\
\hline & $\begin{array}{c}\text { myintkyawthurai sp. } \\
\text { nov. }\end{array}$ & $\begin{array}{l}\text { myintkyawthurai sp. } \\
\text { nov. }\end{array}$ & $\begin{array}{l}\text { myintkyawthurai sp. } \\
\text { nov. }\end{array}$ & $\begin{array}{l}\text { myintkyawthurai sp. } \\
\text { nov. }\end{array}$ & $\begin{array}{l}\text { myintkyawthurai sp. } \\
\text { nov. }\end{array}$ & $\begin{array}{c}\text { myintkyawthurai sp. } \\
\text { nov. }\end{array}$ \\
\hline & Bago Yoma & Bago Yoma & Bago Yoma & Bago Yoma & Bago Yoma & Bago Yoma \\
\hline sex & $\mathrm{f}$ & $\mathrm{f}$ & $\mathrm{f}$ & $\mathrm{f}$ & $\mathrm{m}$ & $\mathrm{m}$ \\
\hline supralabials & 7 & 7 & 7 & 7 & 7 & 7 \\
\hline infralabials & 6 & 6 & 6 & 6 & 6 & 6 \\
\hline $\begin{array}{l}\text { body tubercles low and rounded (dome- } \\
\text { shaped) }\end{array}$ & no & no & no & no & no & no \\
\hline $\begin{array}{l}\text { body tubercles pointed and keeked } \\
\text { (triangular) }\end{array}$ & yes & yes & yes & yes & yes & yes \\
\hline no. of paravertebral tubercles & 28 & 29 & 32 & 30 & 32 & 31 \\
\hline no. longitudinal rows of tubercles & 17 & 19 & 17 & 17 & 18 & 18 \\
\hline no. of ventral scales & 36 & 35 & 35 & 36 & 34 & 35 \\
\hline subdigital lamellae on 4th toe & 17 & 18 & 17 & 17 & 17 & 18 \\
\hline $\begin{array}{l}\text { enlarged femoral scales and precloacal } \\
\text { scales continuous }\end{array}$ & no & no & no & no & no & no \\
\hline total number of femoral pores & 4 & 1 & 0 & 1 & 16 & 13 \\
\hline number of precloacal pores in males & 9 & 5 & 8 & 7 & 9 & 9 \\
\hline post-precloacal scales rows & 2 & 2 & 2 & 2 & 2 & 2 \\
\hline $\begin{array}{l}\text { transeverse subcaudal 2-3 times wider } \\
\text { than long }\end{array}$ & I & yes & yes & yes & 1 & yes \\
\hline dorsal pattern with paravertebrtal elements & yes & yes & yes & yes & yes & yes \\
\hline paravertebral elements not in contact & no & no & no & yes & variable & no \\
\hline number of body bands & 5 & 5 & 5 & 5 & $\sim 5$ & 5 \\
\hline number of light bands on tail & 1 & 1 & 11 & 11 & 1 & 11 \\
\hline number of dark bands on tail & 1 & 1 & 11 & 12 & 1 & 11 \\
\hline SVL & 70 & 69.6 & 68.3 & 55.3 & 61.3 & 47.6 \\
\hline $\mathrm{TL}$ & $\mathrm{r}$ & $\mathrm{r}$ & 76.1 & 58.5 & $\mathrm{~b}$ & 50.7 \\
\hline TW & 6 & 5.4 & 6.3 & 4.8 & 6.5 & 4.6 \\
\hline FL & 9.8 & 10 & 9.4 & 8.6 & 9.1 & 7.6 \\
\hline
\end{tabular}




\begin{tabular}{|c|c|c|c|c|c|c|}
\hline TBL & 11.6 & 10.5 & 11.6 & 9.5 & 10.6 & 8.8 \\
\hline AG & 30.6 & 34.4 & 34.8 & 22.5 & 26.8 & 23.4 \\
\hline $\mathrm{HL}$ & 18.8 & 19.1 & 18.3 & 14.7 & 16.8 & 13.6 \\
\hline HW & 11.6 & 11.2 & 11.9 & 9.7 & 10.5 & 8.2 \\
\hline HD & 7.5 & 7.7 & 9.4 & 5.8 & 6.8 & 5.4 \\
\hline ED & 4.5 & 4.2 & 4.7 & 3.9 & 4.4 & 4.1 \\
\hline $\mathrm{EE}$ & 4.3 & 4.8 & 5.3 & 3.9 & 4.4 & 3.3 \\
\hline ES & 6.8 & 6.8 & 6.9 & 6.2 & 6.6 & 4.7 \\
\hline EN & 4.6 & 5.4 & 5.4 & 4.5 & 5.3 & 3.4 \\
\hline $\mathrm{IO}$ & 5 & 4.5 & 4.5 & 3.8 & 3.9 & 3.1 \\
\hline $\mathrm{EL}$ & 2 & 2.2 & 1.6 & 1.9 & 2.4 & 1.5 \\
\hline IN & 2.4 & 2.3 & 2.2 & 1.7 & 2.4 & 1.8 \\
\hline
\end{tabular}




\section{Table 7 (on next page)}

Summary statistics and diagnostic characters of the species from the peguensis species groups.

SD $=$ standard deviation, and $\mathrm{N}=$ sample size. ${ }^{*}=$ data come from Bauer (2003). 
Table 7 Summary statistics and diagnostic characters of the species from the peguensis species groups. SD $=$ D E standard deviation, and $\mathrm{N}=$ sample size. *

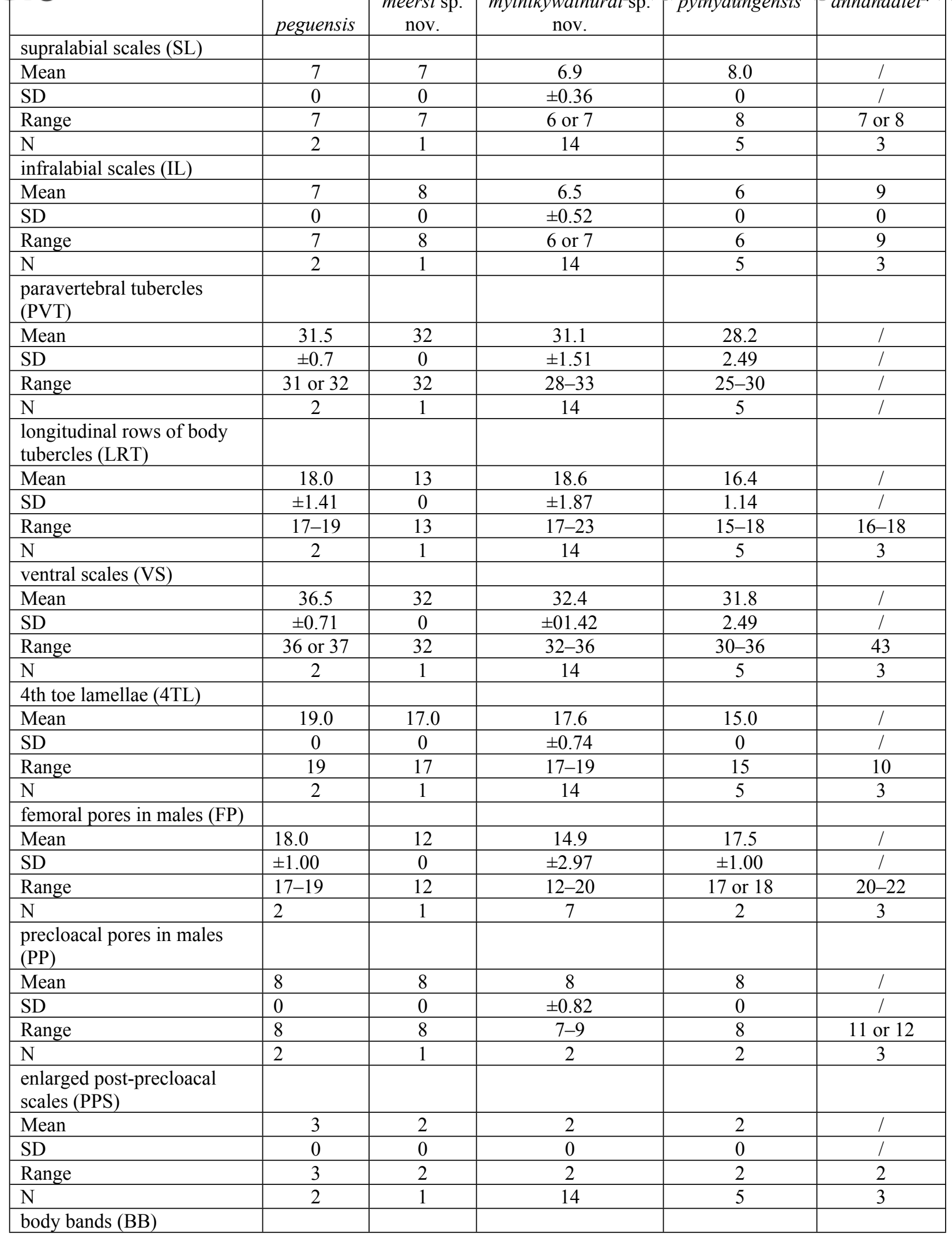




\begin{tabular}{|c|c|c|c|c|c|}
\hline Mean & 5 & 5 & 4.9 & 5.8 & 1 \\
\hline SD & 0 & 0 & \pm 0.66 & 0.45 & 1 \\
\hline Range & 5 & 5 & $4-6$ & 5 or 6 & 4 \\
\hline $\mathrm{N}$ & 2 & 1 & 14 & 5 & 3 \\
\hline \multicolumn{6}{|l|}{ light caudal bands (LCB) } \\
\hline Mean & 12.5 & 11 & 10.8 & 10.8 & 1 \\
\hline SD & \pm 0.50 & 0 & \pm 0.98 & 1.71 & l \\
\hline Range & 12 or $13^{*}$ & 11 & $9-12$ & $9-13$ & 11 \\
\hline $\mathrm{N}$ & 2 & 1 & 6 & 4 & 1 \\
\hline \multicolumn{6}{|l|}{ dark caudal bands (DCB) } \\
\hline Mean & 13 & 10 & 10.8 & 11.0 & 1 \\
\hline SD & 0 & 0 & \pm 0.75 & 1.63 & 1 \\
\hline Range & 13 & 10 & $10-12$ & $9-13$ & 12 \\
\hline $\mathrm{N}$ & 2 & 1 & 6 & 4 & 1 \\
\hline \multicolumn{6}{|l|}{ Morphology } \\
\hline $\begin{array}{l}\text { body tubercles domed to } \\
\text { weakly conical and weakly } \\
\text { keeled }\end{array}$ & yes & yes & no & no & yes \\
\hline $\begin{array}{l}\text { body tubercles raised, } \\
\text { moderately to strongly } \\
\text { keeled }\end{array}$ & no & no & yes & yes & no \\
\hline \multicolumn{6}{|l|}{ Color Pattern } \\
\hline $\begin{array}{l}\text { top of head patternless or } \\
\text { blotched }\end{array}$ & blotched & blotched & blotched & blotched & patternless \\
\hline $\begin{array}{l}\text { paravertebral elements of } \\
\text { dorsal bands confluent }\end{array}$ & variable & yes & variable & yes & yes \\
\hline maximum SVL (mm) & 70 & 36.0 & 75.1 & 71.7 & 55 \\
\hline
\end{tabular}




\section{Table 8 (on next page)}

Pairwise comparison of characters with statistically significant mean differences among species of the peguensis group.

The raw data for Cyrtodactylus annandaeli were unavailable. 
Table 8 Pairwise comparison of characters with statistically significant mean differences among species of the peguensis group. The raw data for Cyrtodactylus annandaeli were unavailable.

\begin{tabular}{|l|c|c|c|c|}
\hline & $\begin{array}{c}\text { meersi } \\
\text { sp. nov. }\end{array}$ & $\begin{array}{c}\text { myintkyawthurai } \\
\text { sp. nov. }\end{array}$ & peguensis & pyinyaungensis \\
\hline meersi sp. nov. & $* * *$ & $* * *$ & $* * *$ & $* * *$ \\
\hline $\begin{array}{l}\text { myintkyawthurai } \\
\text { sp. nov. }\end{array}$ & IL & $* * *$ & $* * *$ & $* * *$ \\
\hline peguensis & LRT & PPS,4TL & $* * *$ & $* * *$ \\
\hline pyinyaungensis & IL,4TL & BB,IL,PV,4TL & IL,LRT,PPS,4TL,VS & $* * *$ \\
\hline
\end{tabular}

1 